In collaboration with the Evansville Area Earthquake Hazards Mapping Project (EAEHMP)

\title{
Liquefaction Hazard for the Region of Evansville, Indiana
}
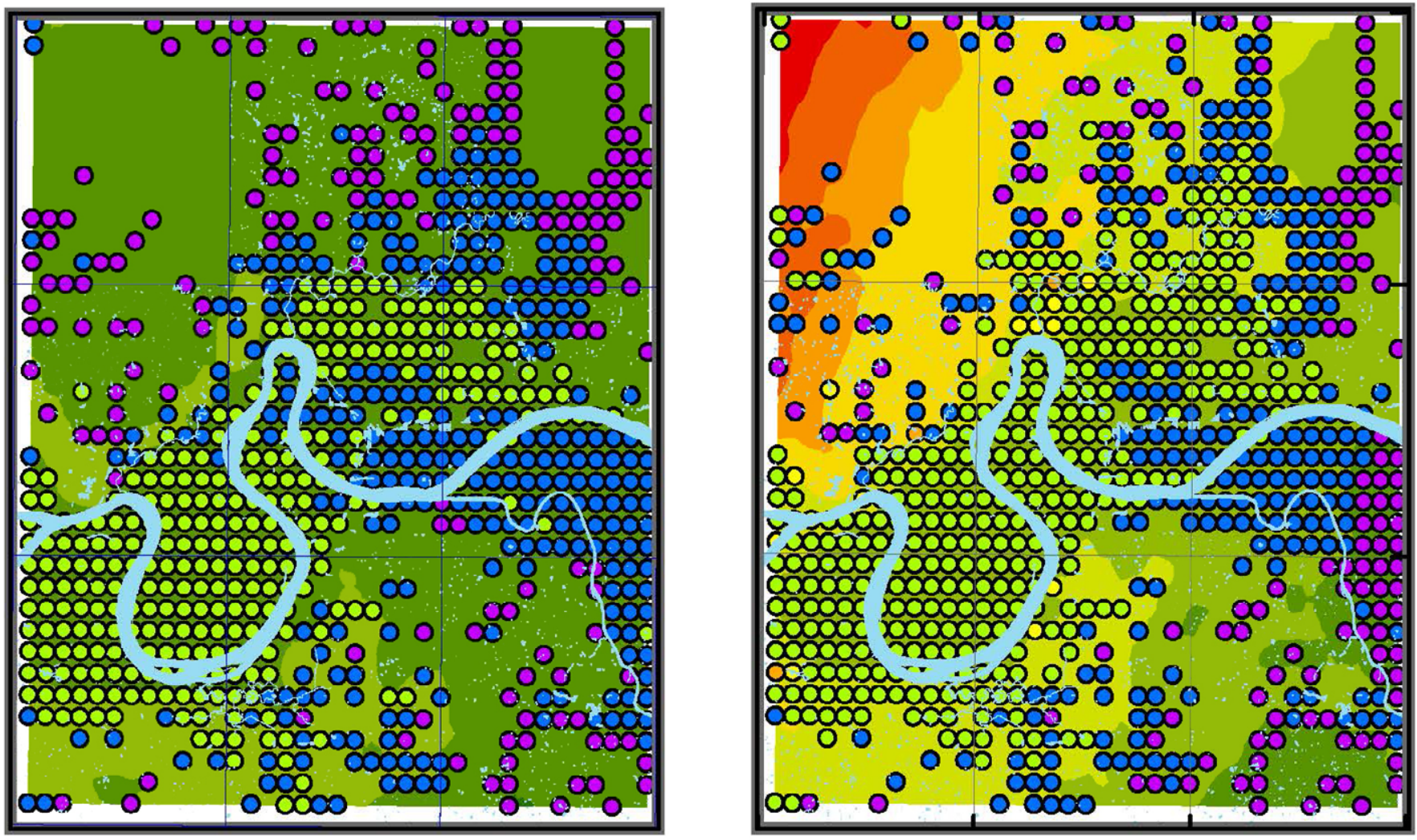

Open-File Report 2011-1203

U.S. Department of the Interior

U.S. Geological Survey 


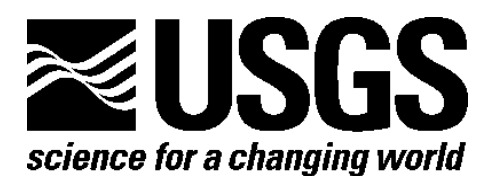

\section{Liquefaction Hazard for the Region of Evansville, Indiana}

By Jennifer S. Haase, Yoon S. Choi, Robert L. Nowack, Chris H. Cramer, Oliver S. Boyd, and Robert A. Bauer

In collaboration with the Evansville Area Earthquake Hazards Mapping Project (EAEHMP)

Open-File Report 2011-1203

U.S. Department of the Interior

U.S. Geological Survey 


\section{U.S. Department of the Interior \\ KEN SALAZAR, Secretary}

U.S. Geological Survey
Marcia K. McNutt, Director

U.S. Geological Survey, Reston, Virginia: 2011

For product and ordering information:

World Wide Web: http://www.usgs.gov/pubprod

Telephone: 1-888-ASK-USGS

For more information on the USGS—-the Federal source for science about the Earth, its natural and living resources, natural hazards, and the environment:

World Wide Web: http://www.usgs.gov

Telephone: 1-888-ASK-USGS

Suggested citation:

Haase, J.S., Choi, Y.S., Nowack, R.L., Cramer, C.H., Boyd, O.S., and Bauer, R.A., 2011, Liquefaction hazard for the region of Evansville, Indiana: U.S. Geological Survey Open-File Report 2011-1203, 37 p.

Any use of trade, product, or firm names is for descriptive purposes only and does not imply endorsement by the U.S. Government.

Although this report is in the public domain, permission must be secured from the individual copyright owners to reproduce any copyrighted material contained within this report. 


\section{Contents}

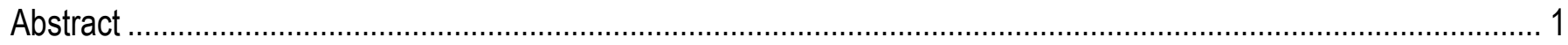

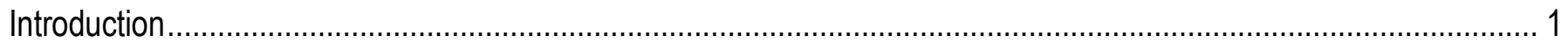

Choice of Scenario Earthquakes for Liquefaction Study ............................................................................ 1

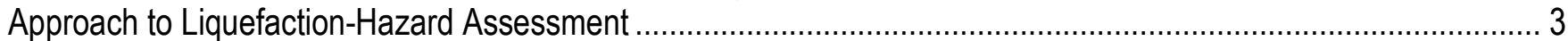

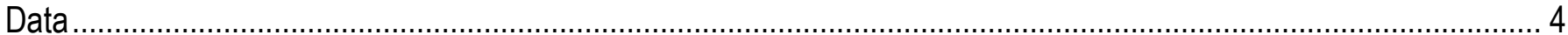

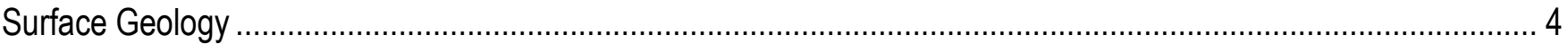

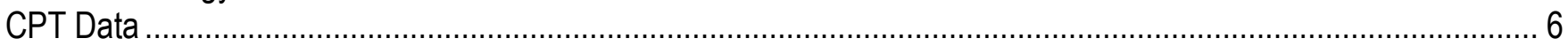

Method of Calculation of Factor of Safety and Liquefaction Potential Index ........................................................ 7

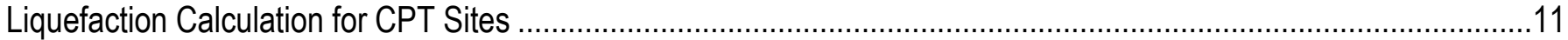

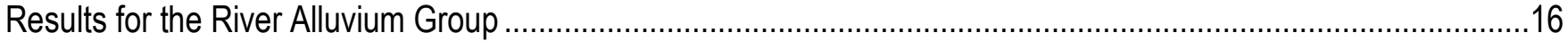

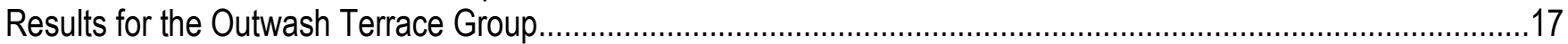

Results for the Lacustrine Terrace Group ..............................................................................................17

Evaluating Liquefaction Potential for Silty and Clayey Soil .........................................................................17

Liquefaction Calculation for non-CPT Sites ..............................................................................................19

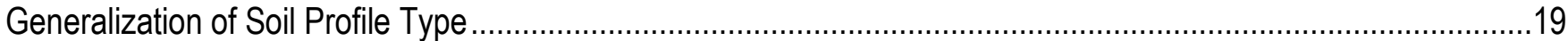

Determining Soil Thickness and Water Table .......................................................................................

Mapping Liquefaction Potential using a Probability-Based Method.....................................................................21

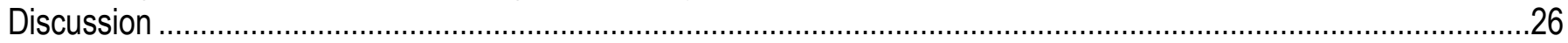



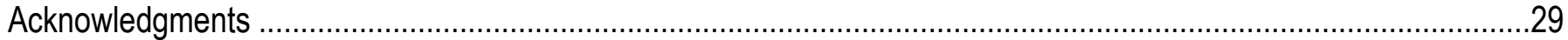

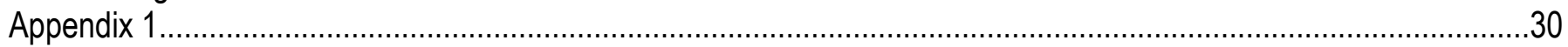

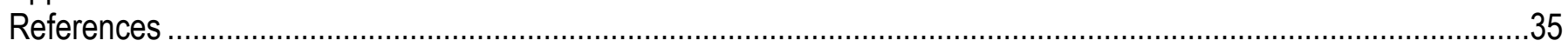

Figures

Figure 1. Merged surficial geologic map from the 1:50,000- and 1:500,000-scale maps including cone-penetrometer test sites with shear wave measurements....................................................... 5

Figure 2. Example of the series of calculations for the factor of safety for profile VHCO06, a typical profile located in unit Qall alluvium levee deposits.

Figure 3. Peak ground acceleration in terms of the percent of the acceleration of gravity predicted for an M7.7 New Madrid earthquake and an M6.8 Wabash Valley earthquake................................... 12

Figure 4. Liquefaction potential index calculated from the cone-penetrometer test profiles for an M7.7 New Madrid event and an M6.8 Wabash Valley event.

Figure 5. Soil-behavior-type index, $l_{c}$, and friction ratio in percent, $F$, plotted for all clay-rich soil elements in the cone-penetrometer test dataset.

Figure 6. Test datasets of plasticity index, water content, and liquid limit from clay units near the cone-penetrometer test profiles within Lacustrine Terrace group that required further testing to determine liquefaction susceptibility

Figure 7. Contoured bedrock depth. The steep-sided ancient bedrock valley is evident beneath the flood plain of the present-day meandering Ohio River....

Figure 8. Examples of the variation of: $A$, the tip resistance, $q_{c}$; and $B$, sleeve friction, $f_{s}$, with depth for all profiles in River alluvium group. Examples of the variation of: $C$, tip resistance, $q_{c}$; and $D$, sleeve friction, $f_{s}$, with depth for all profiles in Outwash terrace group. Examples of the variation of: $E$, tip resistance, $q_{c}$; and $F$, sleeve friction, $f_{s}$, with depth for all profiles in Lacustrine terrace group. 
Figure 9. Mean liquefaction potential index for: $A$, magnitude (M) 7.7 New Madrid scenario earthquake and $B, M 6.8$ Wabash River valley scenario earthquake

Figure 10. Probability that the liquefaction potential index $(L P I)$ is greater than 5 for: $A$, a magnitude (M) 7.7 New Madrid scenario earthquake and $B$, an M6.8 Wabash River valley scenario earthquake. Probability that $L P I$ is greater than 12 for: $C$, an M7.7 New Madrid scenario earthquake and $D$, an M6.8 Wabash River valley scenario earthquake.

Figure 1-1. Group 1, River alluvium, profiles and calculated factor of safety, with soil units taken from Holzer (2003). Units with soil-behavior index less than 2.6 do not contribute to the liquefaction potential index and are indicated with the factor of safety in red

Figure 1-2. Western profiles from group 2, Outwash terrace, and factor of safety with soil units taken from Holzer (2003). Units with soil-behavior index less than 2.6 do not contribute to the liquefaction potential index and are indicated with the factor of safety in red

Figure 1-3. Eastern profiles from group 2, Outwash terrace, and calculated factor of safety with soil units taken from Holzer (2003). Units with soil-behavior index less than 2.6 do not contribute to the liquefaction potential index and are indicated with the factor of safety in red

Figure 1-4. Lacustrine terrace, profiles and calculated factor of safety with soil units taken from Holzer (2003). Units with soil-behavior index less than 2.6 do not contribute to the liquefaction potential index and are indicated with the factor of safety in red

\section{Tables}

Table 1. Soil types associated with variable propensity for liquefaction as adapted from Robertson and Wride (1998)

Table 2. Liquefaction potential index for each cone-penetrometer test measurement listed by surficial geologic unit and grouped based on similarities in soil behavior type and similarities in the lithologic descriptions of the surficial geologic units

Table 3. Comparison of liquefaction potential index calculated using nearby standard-penetration test (SPT) and cone-penetrometer test (CPT) data for several sites within the Lacustrine terrace group. See Holzer (2003) for identification of individual CPT profile locations

Table 4. Comparison of liquefaction potential index calculated using nearby standard-penetration test and cone-penetrometer test data for several sites within the River alluvium group. 


\title{
Liquefaction Hazard for the Region of Evansville, Indiana
}

\author{
By Jennifer S. Haase, ${ }^{1}$ Yoon Seok Choi, ${ }^{2}$ Robert L. Nowack, ${ }^{1}$ Chris H. Cramer, ${ }^{3}$ Oliver S. Boyd,${ }^{4}$ and \\ Robert A. Bauer ${ }^{5}$
}

\begin{abstract}
We calculated liquefaction potential index for a grid of sites in the Evansville, Indiana area for two scenario earthquakes - a magnitude 7.7 in the New Madrid seismic zone and a M6.8 in the Wabash Valley seismic zone. For the latter event, peak ground accelerations range from 0.13 gravity to 0.81 gravity, sufficiently high to be of concern for liquefaction.

Recently acquired cone-penetrometer test data at 58 sites were used to estimate the factor of safety against liquefaction and liquefaction potential index at each site. To extend the estimation of liquefaction hazard to a grid of sites in the area, the soil columns at these grid sites were divided into three categories, and for each category a sufficient number of conepenetrometer test sites were available to characterize statistically each group's conepenetrometer test tip resistance and sleeve friction. At each grid site, Monte Carlo sampling was used to generate values for these two parameters at 2-meter intervals for depths down to 20 meters or bedrock. The groundwater table at each grid site was likewise sampled from a mean value and group-dependent standard deviation. For each grid site, 25,000 realizations of the soil profile were generated and a probability distribution of liquefaction potential index values was obtained.

Maps of liquefaction hazard for each scenario earthquake present (1) Mean liquefaction potential index at each site, and (2) Probabilities that liquefaction potential index values exceed 5 (threshold for expression of surface liquefaction) and 12 (threshold for lateral spreading). Values for the liquefaction potential index are high in the River alluvium group, where the soil profiles are predominantly sand, while values in the Lacustrine terrace group are lower, owing to the predominance of clay. Liquefaction potential index values in the Outwash terrace group are less consistent because the soil profiles contain highly variable sequences of silty sand, clayey sand, and sandy clay, justifying the use of the Monte Carlo procedure to capture the consequences of this complexity.
\end{abstract}

\section{Introduction}

\section{Choice of Scenario Earthquakes for Liquefaction Study}

For the purpose of this and the related studies (Haase and others, 2011a and b), the Evansville Area Earthquake Hazards Mapping Project Technical Working group (a group composed of geoscientists and community professionals) was tasked with the goal of producing

\footnotetext{
${ }^{1}$ Department of Earth and Atmospheric Sciences, Purdue University, West Lafayette, IN 47906.

${ }^{2}$ School of Civil Engineering, Purdue University, West Lafayette, IN.

${ }^{3}$ Center for Earthquake Research and Information, University of Memphis, Memphis, TN.

${ }^{4}$ United States Geological Survey, Memphis, TN.

${ }^{5}$ Illinois State Geological Survey, Champaign, IL.
} 
relevant urban hazard mapping products for the Evansville urban area. The selection of scenario events for deterministic studies took into account the following information.

Evansville, Ind., is a current focus of urban seismic hazard mapping in the Central United States because of its proximity to the New Madrid seismic zone (NMSZ), where a sequence of three earthquakes with magnitude (M) greater than 7 occurred in 1811-1812 (Johnston, 1996; Hough and others, 2000; Bakun and Hopper, 2004). Both the NMSZ and the Wabash Valley seismic zone (WVSZ) are potential source areas for triggering liquefaction in and around Evansville, Ind., and Henderson, Ky., which lie on sequences of alluvial and lacustrine sediments adjacent to the Ohio River. Quarries and river banks in the nearby Wabash Valley show evidence of historic liquefaction, due to two events in the WVSZ at approximately 6,100 years before present (B.P.) and 12,000 B.P. (Munson and Munson, 1996). This study describes liquefactionhazard maps constructed for the Evansville area - these maps are intended as a complement to recent work on scenario earthquake ground motions (Haase and others, 2011b) and a probabilistic seismic hazard analysis (Haase and others, 2011a).

The three large New Madrid earthquakes that occurred in 1811-1812 generated ground shaking throughout the central and eastern United States. Moment magnitudes ranging from magnitude (M) 7.4 to 8.1 have been assigned to the largest of the events based on preinstrumental intensity reports (Johnston, 1996; Hough and others, 2000; Bakun and Hopper, 2004). In southern Indiana, the reported intensities ranged from Modified Mercalli Intensity (MMI) VI to VII (Nuttli, 1973; Street, 1984).

A recurrence of a New Madrid type event is of concern in urban areas such as Evansville, Ind., where some earthquake damage could occur. There is evidence from ancient sand blows that one large earthquake occurred about A.D. 300 and three additional sequences of large earthquakes occurred about A.D. 900, A.D. 1450 and 2350 B.C. in the NMSZ (Tuttle and others, 2002; Tuttle and others, 2005). The sequence in A.D. 1450 may not have ruptured the northernmost arm of the New Madrid fault, and the record might not be complete between 2350 $\mathrm{BC}$ and $1450 \mathrm{AD}$. Based on these data, the recurrence interval for a New Madrid type event has been estimated to be 500 to 1,000 years (yr). However, Calais and Stein (2009) claim that low rates of deformation observed by GPS in the midcontinent indicate that present-day recurrence intervals for a New Madrid type event might be longer than 1,000 yr or that the deformation is not steady in time. Currently a recurrence interval of 500 to 1,000 years has been retained for the calculation of the 2008 United States Geological Survey (USGS) National Seismic Hazard Maps (Petersen and others, 2008).

These recent national maps were de-aggregated (Harmsen and others, 1999) to investigate what earthquake magnitude and location contributes the most to the probabilistic seismic hazard for the Evansville region. We found that a M7.7 earthquake at a distance of 180 $\mathrm{km}$ (that is, a New Madrid type event) makes the greatest contribution to the seismic hazard at all periods for 2-percent probability of exceedance in 50 years (or 1 chance in 2,500 in any year). Therefore, this type of event was selected for simulation deterministically as a scenario earthquake (Haase and Nowack, 2009) and is used here as one of the scenarios for evaluating liquefaction hazard.

Previous work in the Wabash Valley has revealed paleoliquefaction evidence of four past earthquakes of magnitude greater than 6 in the last 12,000 yr (Munson and others, 1995; Munson and Munson, 1996; Pond, 1996; McNulty and Obermeier, 1999; Green and others, 2005; Olson and others, 2005). The closest of those to Evansville was the Skelton-Mt.Carmel earthquake that occurred approximately $12,000 \pm 1,000 \mathrm{yr}$ B.P. and had an estimated magnitude of 6.7-6.8. Although evidence of liquefaction from this pre-historic earthquake is not exposed in Evansville, liquefaction has been observed at greater distances, so this type of Wabash Valley event is of concern (Munson and Munson, 1996). 
The repeat time of earthquakes having M greater than 6 in all of southern Indiana and Illinois is about 1,500 yr; however, it is much lower for any one individual fault. Much of the hazard of the WVSZ in the 2008 USGS National Seismic Hazard Maps is based on seismicity rates derived from catalogs of earthquakes with magnitude 3.0 or greater from 1700 through 2006 (assuming a maximum magnitude of M7.5). The support for a high maximum magnitude in the Wabash Valley relative to the rest of the central United States is based on the paleoliquefaction evidence cited above and worldwide studies of maximum observed earthquake magnitudes in stable continental regions (Johnston, 1994).

The deaggregation of the probabilistic seismic-hazard maps shows that a Wabash-Valley type of event does not make a large contribution to the hazard at a 2-percent probability of exceedance in 50 years, compared to that of the NMSZ. However, because of the proximity of the potential seismic source area to Evansville, and the extensive observations in other locations of historic liquefaction from a Wabash Valley source, a Wabash-Valley type of event was also judged worthy of investigation.

In accord with the above consideration, the Working Group selected two scenario events for detailed investigation: a M7.7 earthquake on the New Madrid fault at an average distance of $180 \mathrm{~km}$ southwest of the center of the study region, and an M6.8 earthquake approximately 40 $\mathrm{km}$ northwest of the center of the study region.

\section{Approach to Liquefaction-Hazard Assessment}

Peak ground acceleration is an essential element in the determination of likelihood of liquefaction for a given soil column. The seismic-hazard assessment of ground motions from these two scenario earthquakes (Haase and others, 2011b) and the probabilistic seismic hazard analysis for the region (Haase and others, 2011a) were carried out using subsurface information on shear-wave velocity, soil type, and soil thickness, in order to incorporate the near-surface amplification or de-amplification due to local site effects into the hazard assessments. These studies revealed that the soils present in the river alluvium in the low-lying regions and in the loess-covered uplands have significantly different properties that affect the spatial distribution of amplification and thus the expected acceleration levels. Within the thickest sediments of the Ohio River Valley, distinct resonant periods between 0.6 to 0.8 seconds (s) create high amplification at 1 -s period. There is also some amplification at higher frequencies outside the river valley. The peak ground acceleration (PGA) having a 2-percent probability of being exceeded in 50 years is $0.3-0.5$ gravity $(\mathrm{g})$ for much of the study region, with values locally as high as $0.66 \mathrm{~g}$. The accelerations resulting from the scenario ground motion analyses, when taking into account the soil response, showed lateral variations similar to the probabilistic analysis for acceleration levels that are important to consider in a study of liquefaction.

Previous studies have investigated the soil conditions present along the Wabash and Ohio Rivers and evaluated the hazard from liquefaction. A study of the glacial outwash deposits at the boundary of the river alluvium in Evansville was carried out using a combination of data from the standard penetration test (SPT) and the cone penetrometer test (CPT). The study showed that the liquefaction hazard had a large range in these deposits (Kayabali, 1993; Kayabali and West, 1994).

Bobet and others (2001) evaluated ground accelerations and liquefaction potential for nine sites in southwestern Indiana to estimate the damage potential to pile foundations at bridge sites. They found soil liquefaction and lateral spreading to be likely at some sites in the thick alluvial deposits of both the Ohio and Wabash River Valleys. While their study investigated individual sites, it did not provide an estimate of liquefaction hazard over the entire Evansville region. 
Recently, more extensive sets of CPT data have been collected to allow better characterization of the soils on a regional scale (Holzer, 2003), detailed surficial mapping has been completed (Moore and others, 2009), and a 3D model of soil depth and properties has been created (Haase and others, 2011a).

Several approaches have been developed to provide an integrated map view of liquefaction hazard, which otherwise depends on depth-dependent soil characteristics. Holzer and others (2006) used liquefaction potential curves (cumulative frequency distributions of the liquefaction potential index-LPI) for soil profiles in different surficial geologic materials to evaluate the liquefaction potential in the greater Oakland, Calif., area. They calculated LPI values for each CPT sounding based on M6.6 and 7.1 scenario earthquakes and determined the percentage of the area predicted to liquefy for each earthquake. Lenz and Baise (2007) evaluated the spatial variability of $L P I$ in the same area using CPT and SPT data assuming (1) the peak ground accelerations from the 10-percent chance in 50 years (2002 USGS National Seismic Hazard Map) and (2) an M6.8 earthquake on the San Andreas Fault. Lenz and Baise suggested that a geo-statistical method for the interpolation of $L P I$ is appropriate to construct a detailed liquefaction map. Rix and Romero-Hudock (2003) produced a liquefaction hazard map for Shelby County (Memphis), Tenn., based on the method of Holzer and others (2009) for a New Madrid scenario earthquake. Cramer and others (2008) used the liquefaction potential curves for Memphis (Rix and Romero-Hudock, 2003) to generate probabilistic liquefaction-hazard maps that provide the probability that liquefaction will occur, given all possible ground motions from all known sources.

The approach in the present study is to use the CPT data of Holzer (2003) that sample the principal surficial geologic units in the Evansville area and to calculate the factor of safety and LPI given the mean peak ground accelerations obtained in our scenario study (Haase and others, 2011b). In successive sections, we

- describe the surface geology and CPT data of the Evansville area,

- review the calculation of the factor of safety and LPI using the method of Robertson and Wride (1998), which is based on the cyclic resistance ratio and cyclic stress ratio and the properties of the soil column,

- present the results for the CPT sites,

- present the statistics of gridded site soil properties and development of the distribution of $L P I$ at each site, and mapping of the results,

- discuss a comparison of results with previous work and assessment of uncertainty, and

- summarize the conclusions.

\section{Data}

\section{Surface Geology}

As a precursor to the study of the probabilistic hazard of ground shaking in the Evansville region (Haase and others, 2011a), surficial geologic mapping was carried out at 1:50,000 scale for seven of the nine USGS map quadrangles surrounding the cities of Evansville and Henderson in the southwestern part of Indiana and Kentucky (Moore and others, 2009). The region was mapped using 23 units with descriptions based on lithology and depositional environment. For the Daylight and Kasson quads (northwestern and northeastern quads), the previously available surficial geologic maps at 1:500,000 scale (Gray, 1989) were used, with revisions to the nomenclature for the units to be consistent with the recent mapping. 
The surficial geology along the Ohio River Valley near Evansville consists of a variety of glacial and interglacial lithologic sequences characterized by a series of fluvial and lake depositional events and also by later deposition of relatively thick Ohio River fluvial deposits (Eggert and others, 1996, 1997a, b) (fig. 1).

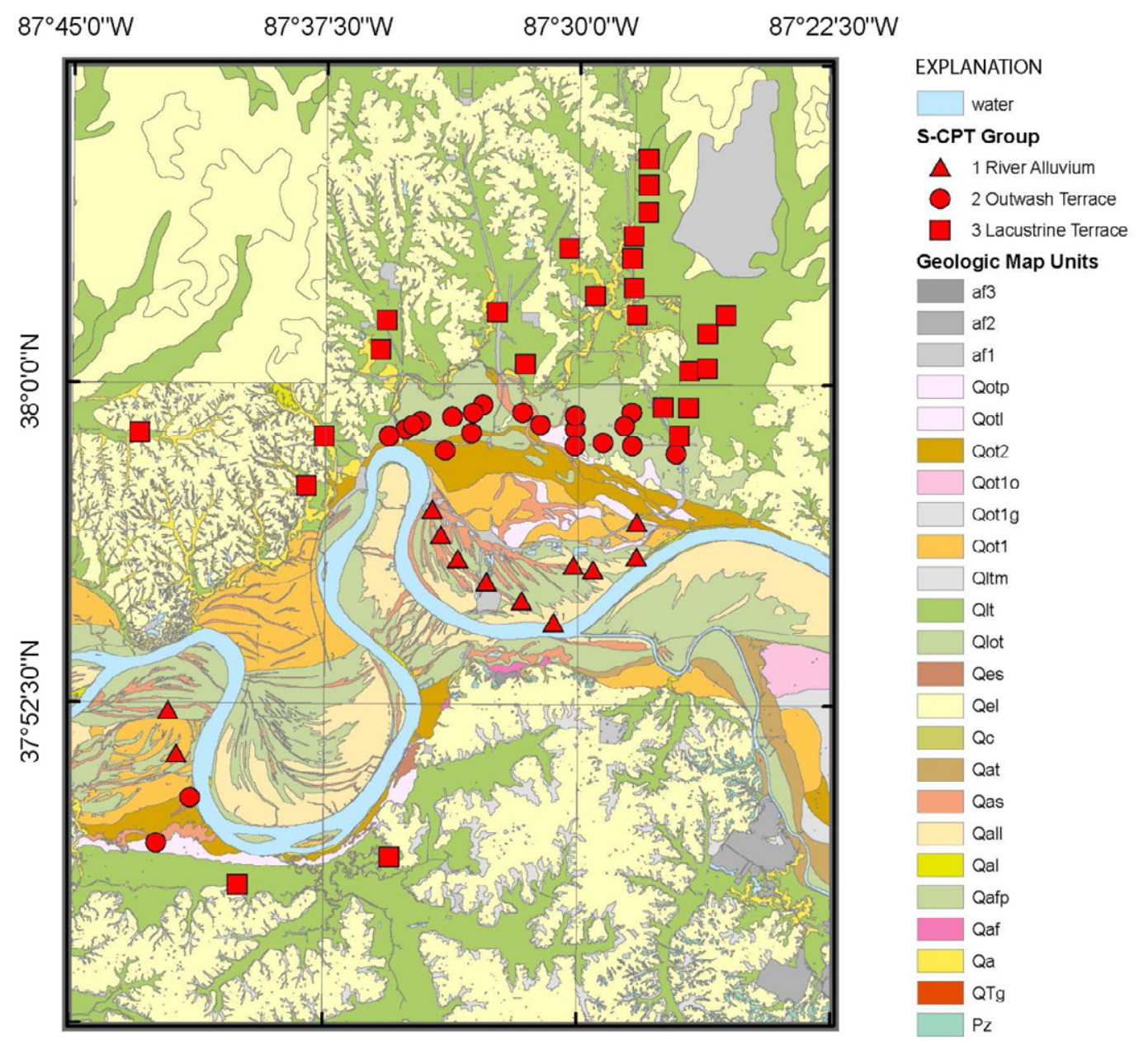

Figure 1. Merged surficial geologic map from the 1:50,000- (Moore and others, 2009) and 1:500,000(Gray, 1989) scale maps including cone-penetrometer test sites with shear wave measurements (red symbols). Mapped units are Quaternary: Qc, colluvium; Qal, alluvium; Qall, levee deposit alluvium; Qas, alluvium in modern flood plain sloughs; Qaf, alluvium in alluvial fans; Qafp, river flood plain alluvium; Qat, low terrace alluvium; Qa, creek and sheetwash alluvium; Qes, dune sand; Qel, loess; Qot10, reworked Ohio River terrace outwash alluvium; Qot1g, reworked Green River terrace alluvium; Qltm, upland marginal lacustrine deposits; Qlt, lacustrine terrace slackwater deposits; Qot1, low terrace outwash alluvium; Qlot, lacustrine and outwash terrace deposits; Qotp, paleolevee deposits on outwash terrace; Qot2, high terrace outwash alluvium; QTg, Quaternary and Tertiary upland gravel; Pz, Paleozoic bedrock; af1, af2, af3, modern artificial fill. Red symbols indicate cone-penetrometer test sites with shear-wave measurements; they are grouped by soil characteristics explained in table 2 . Red triangles are in group 1 (River alluvium group_includes recent and old Ohio River sediments mapped as surficial map units Qaf, Qafp, Qal, Qall, Qas, Qat, Qot1, Qot1g, Qot1o), red circles are in group 2 (Outwash terrace group_includes Qlot, Qot2, Qotp), and red squares are in group 3 (Lacustrine terrace group-includes Qlt, Qa, Qlt, Qltm). 
The fluvial deposits include primarily alluvium and outwash (Qal) and are composed of chiefly fine- to medium-grained lithic quartz sand interbedded with lenses of clay, clayey silt, silt, coarse sand, granules, and gravel (Moore and others, 2009). The typical depositional sequence consists of gravelly sand to sandy gravel at greater depth, predominantly sand at intermediate depths, and silt and clay near the top. A series of terrace deposits bordering the Ohio River Valley are composed primarily of lacustrine and outwash deposits (Qlot). The main urban area of Evansville is constructed on these terrace deposits. Ancient Ohio River tributary valleys are filled with silty and clayey lacustrine terrace deposits (Q1t). The surficial geology in the northern portions of the Evansville region includes loess (Qel) covering the bedrock and lacustrine units.

\section{CPT Data}

Cone-penetrometer tests were carried out at 58 sites (Holzer, 2003) measuring tip resistance, sleeve friction, and shear-wave travel time. The soil type of the layers (table 1) was categorized indirectly by behavior of the tip resistance and sleeve resistance using the method of Roberson and Wride (1998). Based on similarities of the soil types present in the sampled profiles and similarities in the lithologic descriptions of the surficial geologic units, the data from the nine-quadrangle map area (fig. 1) were divided into three groups for analysis as follows: group 1, the River alluvium group, includes recent and old Ohio River sediments mapped as surficial map units Qaf, Qafp, Qal, Qall, Qas, Qat, Qot1, Qot1g, Qot1o; group 2, the Outwash terrace group, includes Qlot, Qot2, Qotp; and group 3, the Lacustrine terrace group, includes Qlt, Qa, Qltm. Among these, 11 CPT measurements were carried out in surficial geologic units included in the River alluvium group, 20 CPT measurements in units included in the Lacustrine terrace group, 24 CPT measurements in units included in the Outwash terrace group (fig. 1), and 3 measurements were taken in other units. An example of the CPT data from one site in the River alluvium group is shown in figure 2. Several profiles constituting cross-sections through the different depositional environments are provided in Appendix 1.

Table 1. Soil types associated with variable propensity for liquefaction as adapted from Robertson and Wride (1998).

\begin{tabular}{c|l}
\hline Soil type & \multicolumn{1}{c}{ Description } \\
\hline 1 & sensitive, fine grained \\
2 & peats \\
3 & silty clay to clay \\
4 & clayey silt to silty clay \\
5 & silty sand to sandy silt \\
6 & clean sand to silty sand \\
7 & gravelly sand to dense sand \\
8 & very stiff sand to clayey sand (heavily overconsolidated or cemented) \\
9 & very stiff, fine grained (heavily overconsolidated or cemented) \\
\hline
\end{tabular}




\section{Method of Calculation of Factor of Safety and Liquefaction Potential Index}

The method of Youd and others (2001) was used to evaluate the liquefaction potential for the Evansville area. Two values are required to calculate the factor of safety for liquefaction: the seismic demand on a soil layer and the soil's capacity to resist liquefaction. The seismic demand is based on the surface peak ground acceleration and the depth to the soil layer through a cyclic stress ratio $(C S R)$. The capacity of the soil to resist is based on the CPT data through a cycle resistance ratio. The factor of safety $(F S)$ is calculated as a function of the cyclic resistance ratio $(C R R)$ for an $\mathrm{M} 7.5$ earthquake $\left(C R R_{7.5}\right)$, the cyclic stress ratio, and a magnitude scaling factor $(M S F)$, to adjust for other magnitudes, and is determined by equation 1.

$$
F S=\left(\frac{C R R_{7.5}}{C S R}\right) \times M S F
$$

A recommended $M S F$ is defined for moment magnitude $(M)$ by the following equation (Youd and others, 2001).

$$
M S F=\frac{10^{2.24}}{M^{2.56}}
$$

The simplified equation for CSR quantifies the stresses produced in the soil by an earthquake and is given by equation 3 .

$$
C S R=0.65\left(\frac{a_{\max }}{g}\right)\left(\frac{\sigma_{v 0}}{\sigma_{v 0}^{\prime}}\right) r_{d}
$$

where:

$a_{\max }$ is the peak ground surface acceleration,

$g$ is the acceleration of gravity,

$\sigma_{\mathrm{v} 0}$ is the total vertical stress,

$r_{\mathrm{d}}$ is the stress-reduction factor at the depth of interest, and

$\sigma_{\mathrm{v} 0}$ is the average effective vertical stress (a function of depth below the water table).

The stress-reduction factor as a function of depth, $z$, is approximated by the following equation (Youd and others, 2001).

$$
r_{d}=\frac{1.000-0.4113 \times z^{0.5}+0.04052 \times z+0.001753 \times z^{1.5}}{1.000-0.4177 \times z^{0.5}+0.05729 \times z-0.006205 \times z^{1.5}+0.001210 \times z^{2}}
$$

The liquefaction resistance of the soil is quantified with the cyclic resistance ratio $(C R R)$ obtained from field cone-penetrometer-test data (CPT) or standard-penetration tests (SPT). For CPT data, the $C R R$ is related to the normalized cone-penetration tip resistance corrected to a clean sand, $\left(q_{c 1 N}\right)_{c s}$, and normalized to 100 kilopascals $(\mathrm{kPa})$, and is given by equation 5 (Robertson and Wride, 1998).

$$
C R R_{7.5}=\left\{\begin{array}{l}
0.833\left[\frac{\left(q_{c 1 N}\right)_{c s}}{1000}\right]+0.05 \text { if }\left(q_{c 1 N}\right)_{c s}<50 \\
93\left[\frac{\left(q_{c 1 N}\right)_{c s}}{1000}\right]^{3}+0.08 \text { if } 50 \leq\left(q_{c 1 N}\right)_{c s}<160
\end{array}\right.
$$


The normalized cone-tip resistance is corrected for overburden stress in the following manner.

$$
q_{c 1 N}=\left(\frac{q_{c}}{P_{a}}\right) C_{Q} \quad \text { with } C_{Q}=\left(\frac{P_{a}}{\sigma_{v 0}^{\prime}}\right)^{n}
$$

where:

$P_{a}$ is the atmospheric pressure equal to $100 \mathrm{kPa}$,

$C_{Q}$ is the normalizing factor for cone-penetration resistance,

$n$ is an exponent that varies with soil type, and

$q_{c}$ is the cone tip resistance measured in the field.

A correction factor, $K_{c}$, which is a function of soil-behavior-type index, $I_{c}$, is applied to correct for the apparent fines content in the soil as shown below.

$$
\left(q_{c 1 N}\right)_{c s}=K_{c} q_{c 1 N}
$$

where:

$$
K_{c}=\left\{\begin{array}{l}
1.0 \text { for } I_{c} \leq 1.64 \\
-0.403 I_{c}^{4}+5.581 I_{c}^{3}-21.63 I_{c}^{2}+33.75 I_{c}-17.88 \text { for } I_{c}>1.64
\end{array}\right.
$$

The soil-behavior-type index, $I_{c}$, is a function of the cone tip resistance $q_{c}$ and the measured sleeve resistance, $f_{s}$, and is given by equation 9 .

$$
I_{c}=\left[(3.47-\log Q)^{2}+(1.22+\log F)^{2}\right]^{0.5}
$$

where:

$$
Q=\left[\frac{\left(q_{c}-\sigma_{v 0}\right)}{P_{a}}\right]\left[\frac{P_{a}}{\sigma^{\prime}{ }^{\prime}}\right]^{n}
$$

and

$$
F=\left\lfloor\frac{f_{s}}{\left(q_{c}-\sigma_{v 0}\right)}\right\rfloor \times 100 \%
$$

Here, $n$ is 0 or 1 depending on the type of soil.

Figure 2 shows the entire calculation for $L P I$ for a typical profile located in the river alluvium. The CPT measurements of tip resistance and sleeve friction are shown in figures $2 A$ and $B$. Soil behavior type classification is shown in figure $2 C$. The series of calculations for the factor of safety is shown in figures $2 D$ through $J$. Figure $2 D$ shows the normalized CPT penetration resistance. Figures $2 F$ and $G$ show soil-behavior-type index $\left(I_{c}\right)$ and correction factor $\left(K_{c}\right)$, necessary to correct soils with fines content to a reference clean sand. Figure $2 I$ shows corrected tip resistance. Figure $2 \mathrm{H}$ shows normalized CPT resistance corrected for overburden stress. The other figures are understandable as labeled.

This soil-column example, VHC006, (fig. 2C) shows three typical soil-behavior types that are found in many of the profiles. It has a sequence of 6 meters $(\mathrm{m})$ of predominantly silty clay to clay layers (soil behavior type 3), overlying a 5-m sequence of predominantly sandy silt to clayey silt (soil behavior type 6), overlying a 9-m sequence of old Ohio River sands and gravelly sand (soil behavior type 8 and 9). The near surface (top $2 \mathrm{~m}$ ) in the clay sequence has a 
relatively high corrected tip resistance, $\left(q_{c 1 N}\right)_{c s}$, leading to a sufficiently high factor of safety to inhibit liquefaction. $I_{c}$ and $K_{c}$ are high in the top sequence, which is identified as clay. The intermediate-depth sequence also indicates significant fines content leading to a moderate correction factor $K_{c}$. The intermediate depth silty sand sequence has a slow increase in CSR due to the increase in effective vertical stress below the water table at $0.8 \mathrm{~m}$ (fig. $2 J$ ).

In addition, this sequence has a relatively low corrected-tip resistance and a low sleeve friction. This leads to a low factor of safety. Figures $2 K$ and $L$ show that many points in the clay sequence that have a low factor of safety are excluded from the calculation of liquefaction potential index because they have been identified as soils with $I_{c}$ greater than or equal to 2.6; that is, they are not susceptible to liquefaction because of their very high clay content. Overall, the liquefaction potential index is high for this site because of the low factor of safety in this intermediate-depth silty sand sequence (fig. $2 K$ ).

The factor of safety is calculated for each soil measurement within the profile at $5-\mathrm{cm}$ depth intervals. The LPI integrates this information over the entire profile and gives a single number that is representative of the probability that any of the susceptible soils will liquefy. The $L P I$ is defined by Iwasaki and others (1982) as

$$
L P I=\int_{0 m}^{20 m} F \times w(z) d z
$$

where:

$$
\begin{aligned}
& F=\left\{\begin{array}{cl}
1-F S & \text { for } F S \leq 1 \\
0 & \text { for } F S>1 \text { or } I_{c}>2.6
\end{array}\right. \\
& w(z)=10-0.5 z
\end{aligned}
$$

and $z$ is the depth below the ground surface in meters, The integral in equation 12 is calculated for the first $20 \mathrm{~m}$ below the surface. The weights, $w(z)$, in the integrand tend to reduce the overall influence of the contributions from deep soil layers. The LPI can be considered primarily as a function of the thickness of the liquefiable layer, the proximity of the liquefiable layer to the surface, and the value of the layer's $F S$ when the $F S$ is less than 1. Note that most clay and silty clay layers at shallow and intermediate depths in this profile are excluded from the calculation when their soil behavior index $I_{c}$ is less than 2.6. This will be discussed in more detail in a later section.

The liquefaction potential was originally classified by Iwasaki and others (1982) to relate the LPI to whether severe liquefaction was likely, based on standard penetration test data. Toprak and Holzer (2003) found that during the Loma Prieta earthquake in 1989, the median value of $L P I$ for soundings where sand boils occurred was 5 , and 25 percent of soundings that showed sand boils had $L P I$ greater than 10 . The median value of $L P I$ for soundings where lateral spreading occurred was 12 , with 25 percent of soundings that showed lateral spreading having LPI greater than 17. Based on these calibrated values, it was proposed that the LPI greater than 5 criteria be used to predict the probability of surface manifestations of liquefaction, and the LPI greater than 12 criteria be used to predict the probability of lateral spreading (Holzer, 2008). We have adopted these criteria for the Evansville liquefaction hazard maps. 

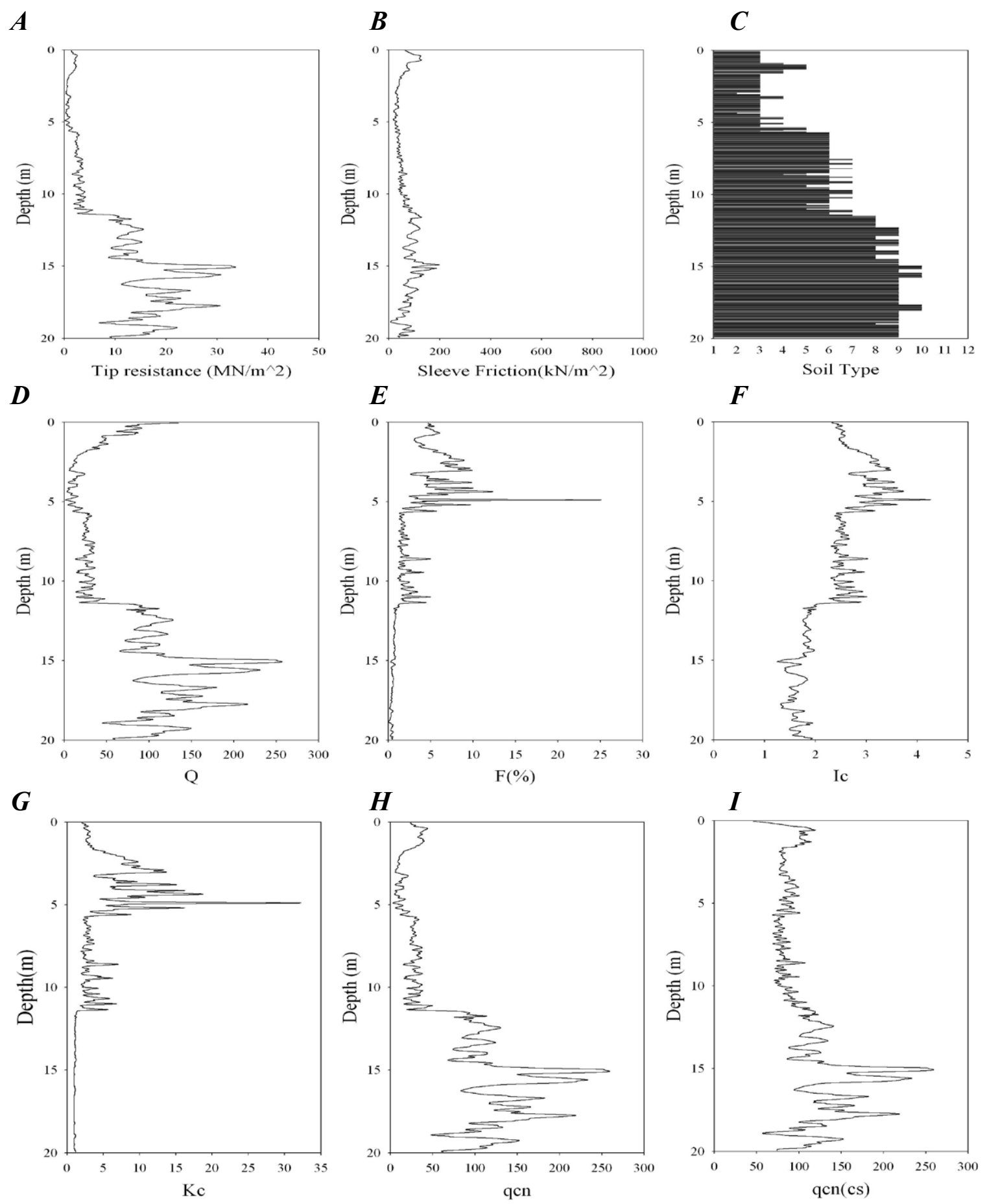

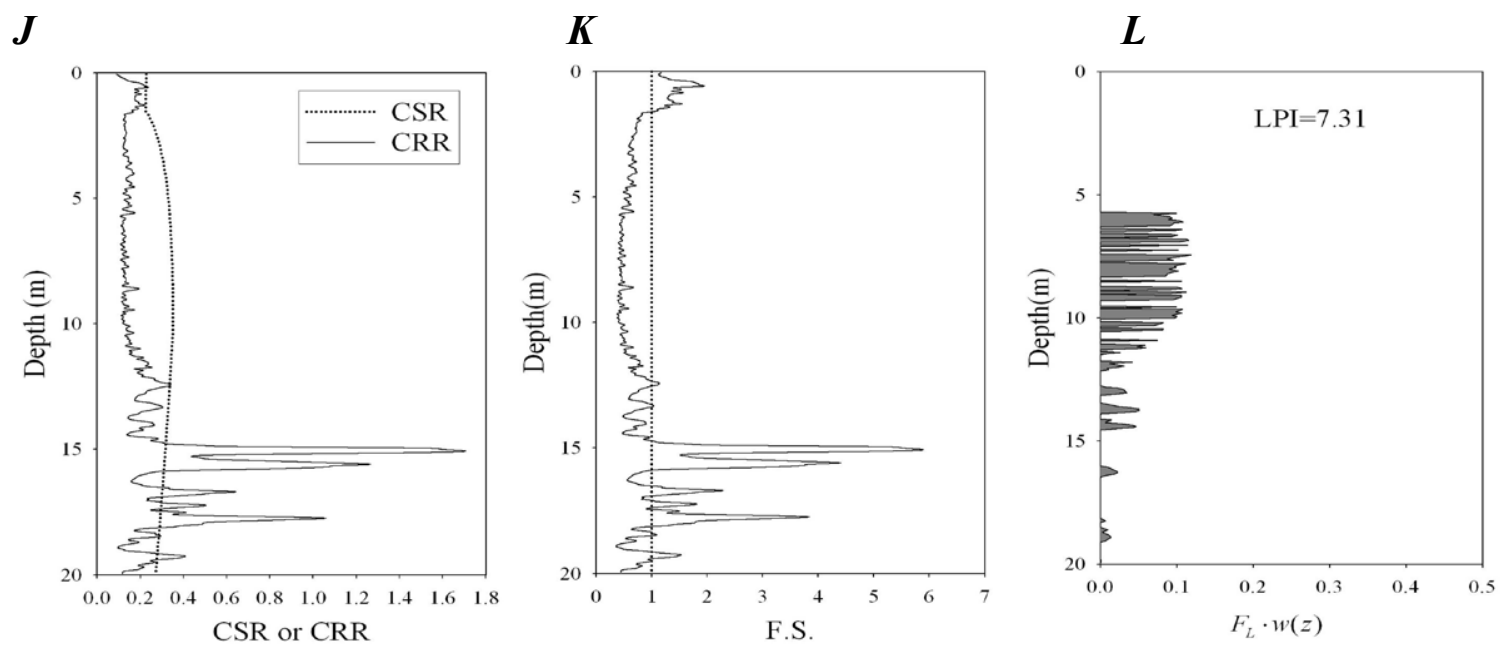

Figure 2. Example of the series of calculations for the factor of safety for profile VHC006, a typical profile located in unit Qall alluvium levee deposits. $A, q_{c}$ : tip resistance; $B, f_{s}$ : sleeve friction; $C$, soil behavior type (Robertson, 1990); $D, Q$ : normalized penetration resistance; $E, F$ : normalized sleeve friction; $F, I_{c}$ : Soil behavior type index; $G, K_{c}$ : correction factor; $H, q_{c 1 N}$ : tip resistance normalized for overburden stress; $I,\left(q_{c 1 N}\right)_{c s}$ : tip resistance corrected to a clean sand; J, CSR and CRR; $K$, factor of safety with dotted line indicating $F S=1$, above which there is no contribution to the $L P I$; and $L$, weighted liquefaction potential integrand $F_{L} \times w(z)$. (MN, megaNewtons; $\mathrm{kN}$, kiloNewton; m, meter).

\section{Liquefaction Calculation for CPT Sites}

For each site, including CPT sites, peak ground accelerations were calculated for the two scenario events described above: an M7.7 earthquake on the New Madrid fault at an average distance of $180 \mathrm{~km}$ southwest of the center of the study region, and an M6.8 earthquake approximately $40 \mathrm{~km}$ northwest of the center of the study region. The calculation uses a suite of alternative seismic-attenuation relations and corresponding weights consistent with the attenuation relations and weights used in the 2008 USGS national seismic hazard maps. The calculation incorporates subsurface geological information to take into account site effects, including amplitude-dependent amplifications (Haase and others, 2011b). The predicted peak ground accelerations $\left(a_{\max }\right)$ for these two events are shown in figure 3 and range from 0.13-0.81 $\mathrm{g}$ for the M6.8 event and 0.09-0.24 g for the M7.7 event (Haase and others, 2011b). 


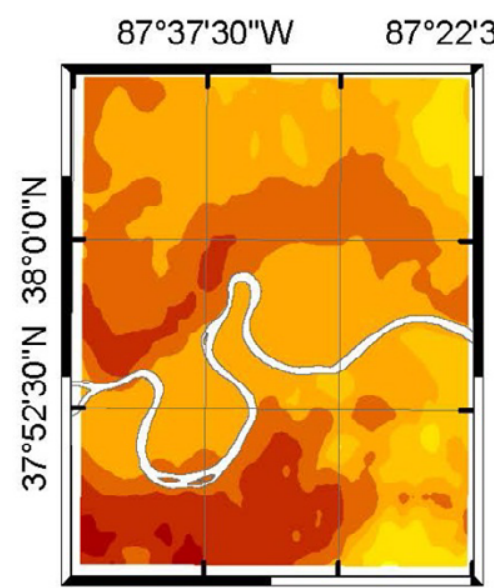

New Madrid M7.7

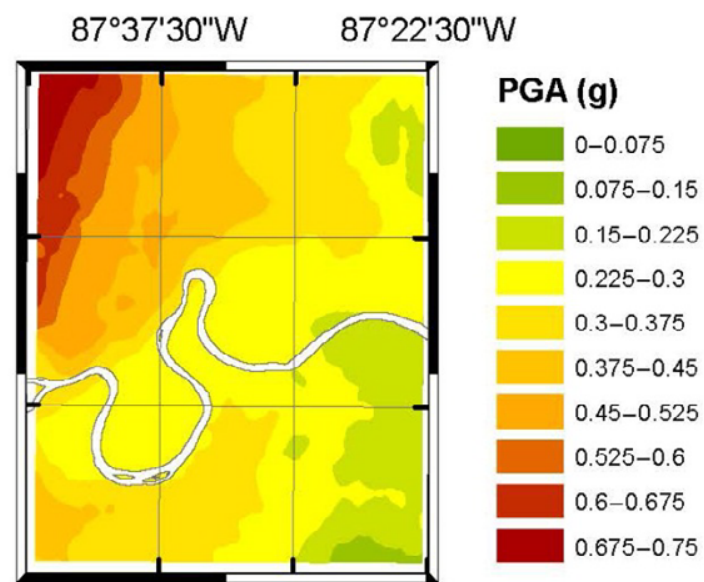

Wabash Valley M6.8

Figure 3. Peak ground acceleration in terms of the percent of the acceleration of gravity (g) predicted for (left) an M7.7 New Madrid earthquake and (right) an M6.8 Wabash Valley earthquake. (PGA, peak ground acceleration)

The $L P I$ is calculated using the procedure described in the previous section at each CPT site for the two scenario earthquakes (fig. 4). Two sites in the River Alluvium group have LPI greater than 5 for the New Madrid event and four sites greater than 5 for the Wabash Valley event, indicating a high probability for liquefaction. The Outwash Terrace group has six sites with $L P I$ greater than 5 for the New Madrid event and seven sites for the Wabash Valley event. Four of these sites have $L P I$ greater than 12 for both scenario events, indicating a high probability of lateral spreading due to liquefaction. The Lacustrine Terrace group has no sites with $L P I$ greater than 5, hence no sites with a high probability of liquefaction. The $L P I$ is very low or exactly zero for many sites in this group, because many soil layers had $I_{c}$ greater than or equal to 2.6, indicating clay content high enough that the layers did not contribute to the $L P I$. Within the Outwash Terrace sites, the sites that are located farther to the west in unit Qlot lacustrine and outwash terrace deposits have higher LPI than those sites to the east for both scenario events. This is because of amplified PGA values to the west within this unit due to site conditions in the unconsolidated soils (figure 3). 

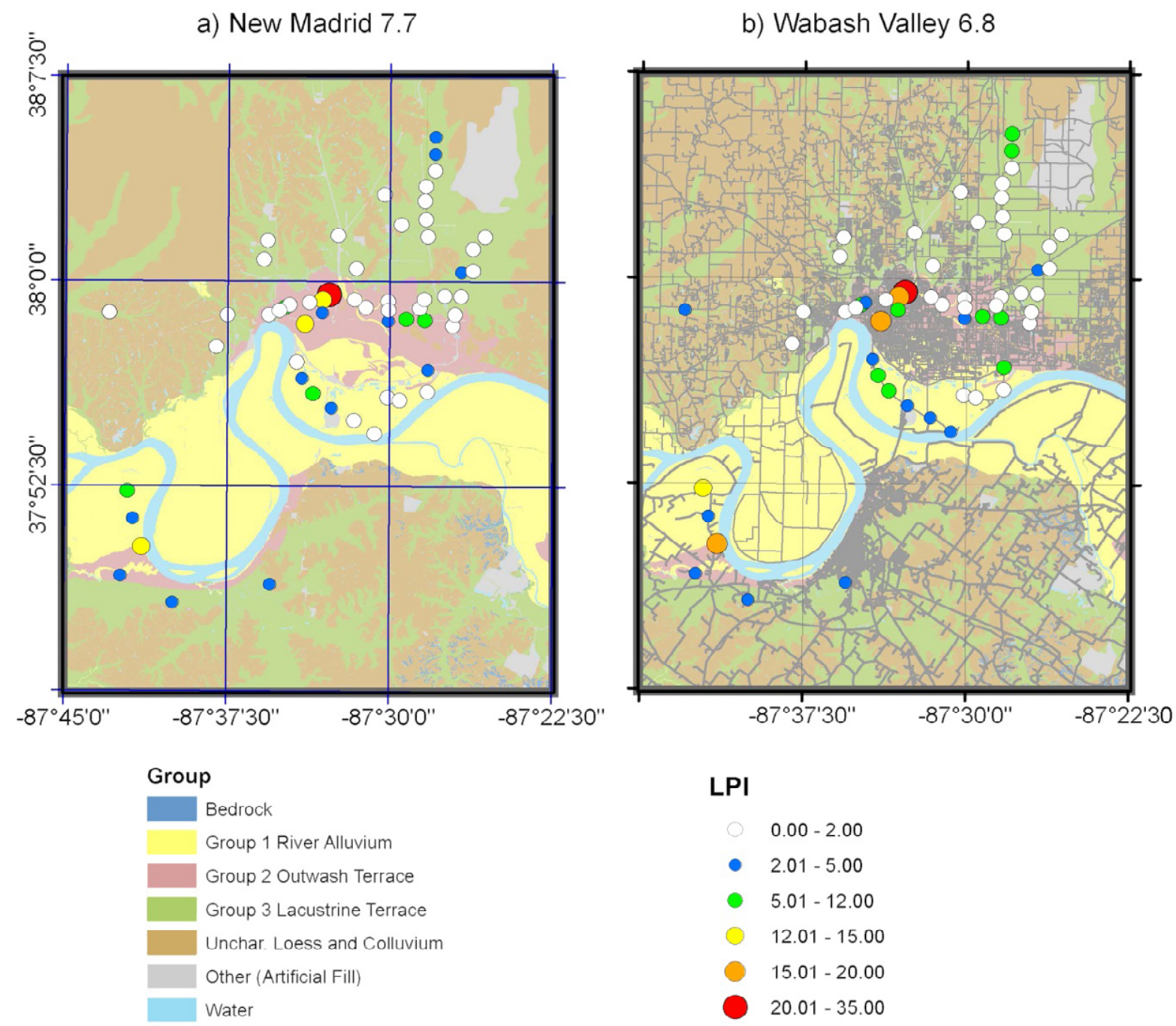

Figure 4. Liquefaction potential index (LPI) calculated from the cone-penetrometer test (CPT) profiles for (left) an M7.7 New Madrid event and (right) an M6.8 Wabash Valley event.

The $L P I$ results are listed in table 2 for each of the CPT profiles from the three groups to illustrate how the surficial geology correlates with the results of the liquefaction calculation. Several examples of typical CPT profiles from each group, and their corresponding factor of safety (calculated assuming a value of $a_{\max }$ of $0.37 \mathrm{~g}$ ), are shown in Appendix 1. The cumulative frequency distributions of $L P I$ are calculated for each group for the larger $a_{\max }$ event, the M6.8 Wabash Valley event. For group 1, River Alluvium, 25 percent of the $L P I$ values exceed 5 (high probability for liquefaction). For group 2, Outwash Terrace, 33 percent of the $L P I$ values exceed 5. For group 3, Lacustrine Terrace, 8 percent of the $L P I$ values exceeds 5. 
Table 2. Liquefaction potential index (LPI) for each cone-penetrometer test measurement listed by surficial geologic unit and grouped based on similarities in soil behavior type and similarities in the lithologic descriptions of the surficial geologic units.

\begin{tabular}{|c|c|c|c|c|c|c|c|}
\hline Sounding & $\begin{array}{l}\text { Latitude } \\
\text { (N) }\end{array}$ & $\begin{array}{l}\text { Longitude } \\
\text { (W) }\end{array}$ & $\begin{array}{c}\mathrm{LPI} \\
(\mathrm{M}=7.7)\end{array}$ & $\begin{array}{c}\text { LPI } \\
(M=6.8)\end{array}$ & Label & Geological Description & Group \\
\hline VHCO05 & 37.9411 & -87.5680 & 3.40 & 5.62 & Qafp & Alluvium, river flood plains (Holocene) & 1 \\
\hline VHCO09 & 37.9155 & -87.5278 & 1.96 & 2.35 & Qafp & Alluvium, river flood plains (Holocene) & 1 \\
\hline VHC010 & 37.9229 & -87.5453 & 3.29 & 3.80 & Qafp & Alluvium, river flood plains (Holocene) & 1 \\
\hline $\mathrm{HNCO05}$ & 37.8721 & -87.7019 & 9.84 & 13.73 & Qafp & Alluvium, river flood plains (Holocene) & 1 \\
\hline VHC001 & 37.9278 & -87.4928 & 0.21 & 0.21 & Qall & Alluvium, natural levee deposits (Holocene) & 1 \\
\hline VHC002 & 37.9329 & -87.4714 & 0.10 & 0.08 & Qall & Alluvium, natural levee deposits (Holocene) & 1 \\
\hline VHC006 & 37.9318 & -87.5595 & 7.62 & 9.00 & Qall & Alluvium, natural levee deposits (Holocene) & 1 \\
\hline VHC007 & 37.9294 & -87.5023 & 0.59 & 0.66 & Qall & Alluvium, natural levee deposits (Holocene) & 1 \\
\hline VHC008 & 37.9072 & -87.5120 & 1.82 & 2.59 & Qall & Alluvium, natural levee deposits (Holocene) & 1 \\
\hline $\mathrm{VHC003}$ & 37.9463 & -87.4712 & 4.73 & 5.01 & Qot1 & $\begin{array}{l}\text { Alluvium, outwash, low terrace } \\
\text { Pleistocene) }\end{array}$ & 1 \\
\hline $\mathrm{HNC004}$ & 37.8552 & -87.6978 & 2.04 & 2.83 & Qot1 & $\begin{array}{l}\text { Alluvium, outwash, low terrace } \\
\text { Pleistocene) }\end{array}$ & 1 \\
\hline VHC013 & 37.9894 & -87.4738 & 0.07 & 0.19 & Qlot & $\begin{array}{l}\text { Lacustrine and outwash terrace deposits } \\
\text { (upper Pleistocene) }\end{array}$ & 2 \\
\hline VHC015 & 37.9840 & -87.4774 & 0.14 & 0.18 & Qlot & $\begin{array}{l}\text { Lacustrine and outwash terrace deposits } \\
\text { (upper Pleistocene) }\end{array}$ & 2 \\
\hline VHC016 & 37.9775 & -87.4880 & 8.73 & 10.02 & Qlot & $\begin{array}{l}\text { Lacustrine and outwash terrace deposits } \\
\text { (upper Pleistocene) }\end{array}$ & 2 \\
\hline VHC018 & 37.9828 & -87.5016 & 0.71 & 0.87 & Qlot & $\begin{array}{l}\text { Lacustrine and outwash terrace deposits } \\
\text { (upper Pleistocene) }\end{array}$ & 2 \\
\hline VHC019 & 37.9880 & -87.5017 & 1.18 & 1.70 & Qlot & $\begin{array}{l}\text { Lacustrine and outwash terrace deposits } \\
\text { (upper Pleistocene) }\end{array}$ & 2 \\
\hline $\mathrm{VHCO2O}$ & 37.9732 & -87.4519 & 0.57 & 0.94 & Qlot & $\begin{array}{l}\text { Lacustrine and outwash terrace deposits } \\
\text { (upper Pleistocene) }\end{array}$ & 2 \\
\hline VHC021 & 37.9920 & -87.5474 & 23.80 & 30.59 & Qlot & $\begin{array}{l}\text { Lacustrine and outwash terrace deposits } \\
\text { (upper Pleistocene) }\end{array}$ & 2 \\
\hline VHC023 & 37.9892 & -87.5277 & 0.34 & 0.70 & Qlot & $\begin{array}{l}\text { Lacustrine and outwash terrace deposits } \\
\text { (upper Pleistocene) }\end{array}$ & 2 \\
\hline VHC026 & 37.9873 & -87.5623 & 0.78 & 1.74 & Qlot & $\begin{array}{l}\text { Lacustrine and outwash terrace deposits } \\
\text { (upper Pleistocene) }\end{array}$ & 2 \\
\hline VHC027 & 37.9856 & -87.5779 & 0.74 & 3.50 & Qlot & $\begin{array}{l}\text { Lacustrine and outwash terrace deposits } \\
\text { (upper Pleistocene) }\end{array}$ & 2 \\
\hline VHC028 & 37.9824 & -87.5855 & 0.00 & 0.05 & Qlot & $\begin{array}{l}\text { Lacustrine and outwash terrace deposits } \\
\text { (upper Pleistocene) }\end{array}$ & 2 \\
\hline VHC032 & 37.9797 & -87.5937 & 0.88 & 1.81 & Qlot & $\begin{array}{l}\text { Lacustrine and outwash terrace deposits } \\
\text { (upper Pleistocene) }\end{array}$ & 2 \\
\hline VHC033 & 37.9840 & -87.5816 & 8.04 & 9.16 & Qlot & $\begin{array}{l}\text { Lacustrine and outwash terrace deposits } \\
\text { (upper Pleistocene) }\end{array}$ & 2 \\
\hline VHC034 & 37.9890 & -87.5521 & 12.52 & 17.09 & Qlot & $\begin{array}{l}\text { Lacustrine and outwash terrace deposits } \\
\text { (upper Pleistocene) }\end{array}$ & 2 \\
\hline VHC025 & 37.9810 & -87.5528 & 2.35 & 5.44 & Qot2 & $\begin{array}{l}\text { Alluvium, outwash, high terrace } \\
\text { (upper Pleistocene) }\end{array}$ & 2 \\
\hline VHC035 & 37.9742 & -87.5659 & 12.19 & 17.47 & Qot2 & $\begin{array}{l}\text { Alluvium, outwash, high terrace } \\
\text { Pleistocene) }\end{array}$ & 2 \\
\hline $\mathrm{HNCO03}$ & 37.8382 & -87.6908 & 12.29 & 15.58 & Qot2 & $\begin{array}{ll}\text { Alluvium, outwash, high terrace } & \text { (upper } \\
\text { Pleistocene) } & \end{array}$ & 2 \\
\hline VHC017 & 37.9763 & -87.5019 & 3.51 & 4.44 & Qotp & $\begin{array}{l}\text { Paleolevee deposits on outwash terrace } \\
\text { (upper Pleistocene) }\end{array}$ & 2 \\
\hline VHCO24 & 37.9843 & -87.5190 & 0.80 & 1.16 & Qotp & $\begin{array}{l}\text { Paleolevee deposits on outwash terrace } \\
\text { (upper Pleistocene) }\end{array}$ & 2 \\
\hline HNC006 & 37.8204 & -87.7073 & 3.10 & 4.44 & Qotp & Paleolevee deposits on outwash terrace & 2 \\
\hline
\end{tabular}


(upper Pleistocene)

\begin{tabular}{|c|c|c|c|c|c|c|c|}
\hline VHC036 & 37.9796 & -87.6256 & 0.64 & 1.34 & $\mathrm{Qa}$ & $\begin{array}{l}\text { Creek alluvium and sheetwash alluvium } \\
\text { (Holocene) }\end{array}$ & 3 \\
\hline VHC037 & 37.9602 & -87.6341 & 0.31 & 1.26 & $\mathrm{Qa}$ & $\begin{array}{l}\text { Creek alluvium and sheetwash alluvium } \\
\text { (Holocene) }\end{array}$ & 3 \\
\hline VHC011 & 37.9913 & -87.4582 & 0.06 & 0.09 & Qlt & $\begin{array}{l}\text { Slackwater deposits, lacustrine terrace (upper } \\
\text { Pleistocene) }\end{array}$ & 3 \\
\hline VHC014 & 38.0275 & -87.4714 & 0.20 & 0.59 & Qlt & $\begin{array}{l}\text { Slackwater deposits, lacustrine terrace (upper } \\
\text { Pleistocene) }\end{array}$ & 3 \\
\hline VHC022 & 38.0080 & -87.5264 & 0.00 & 0.11 & Qlt & $\begin{array}{l}\text { Slackwater deposits, lacustrine terrace (upper } \\
\text { Pleistocene) }\end{array}$ & 3 \\
\hline VHC030 & 38.0495 & -87.4738 & 0.08 & 0.11 & Qlt & $\begin{array}{l}\text { Slackwater deposits, lacustrine terrace (upper } \\
\text { Pleistocene) }\end{array}$ & 3 \\
\hline VHC031 & 38.0349 & -87.4919 & 0.00 & 0.00 & Qlt & $\begin{array}{l}\text { Slackwater deposits, lacustrine terrace (upper } \\
\text { Pleistocene) }\end{array}$ & 3 \\
\hline VHC038 & 38.0250 & -87.5949 & 0.56 & 1.34 & Qlt & $\begin{array}{l}\text { Slackwater deposits, lacustrine terrace (upper } \\
\text { Pleistocene) }\end{array}$ & 3 \\
\hline VHC039 & 38.0135 & -87.5978 & 0.19 & 0.45 & Qlt & $\begin{array}{l}\text { Slackwater deposits, lacustrine terrace (upper } \\
\text { Pleistocene) }\end{array}$ & 3 \\
\hline VHC040 & 38.0532 & -87.5050 & 0.24 & 1.21 & Qlt & $\begin{array}{l}\text { Slackwater deposits, lacustrine terrace (upper } \\
\text { Pleistocene) }\end{array}$ & 3 \\
\hline WKC001 & 37.9911 & -87.4456 & 0.35 & 0.64 & Qlt & $\begin{array}{l}\text { Slackwater deposits, lacustrine terrace (upper } \\
\text { Pleistocene) }\end{array}$ & 3 \\
\hline WKC002 & 38.0058 & -87.4454 & 2.84 & 3.25 & Qlt & $\begin{array}{l}\text { Lacustrine terrace deposit } \\
\text { (upper Pleistocene) }\end{array}$ & 3 \\
\hline WKC003 & 38.0067 & -87.4365 & 0.24 & 0.69 & Qlt & $\begin{array}{l}\text { Lacustrine terrace deposit } \\
\text { (upper Pleistocene) }\end{array}$ & 3 \\
\hline WKC004 & 38.0201 & -87.4365 & 0.16 & 0.35 & Qlt & $\begin{array}{l}\text { Lacustrine terrace deposit } \\
\text { (upper Pleistocene) }\end{array}$ & 3 \\
\hline WKC005 & 38.0274 & -87.4274 & 0.12 & 0.20 & Qlt & $\begin{array}{l}\text { Lacustrine terrace deposit } \\
\text { (upper Pleistocene) }\end{array}$ & 3 \\
\hline WKC006 & 38.0885 & -87.4658 & 4.69 & 6.11 & Qlt & $\begin{array}{l}\text { Lacustrine terrace deposit } \\
\text { (upper Pleistocene) }\end{array}$ & 3 \\
\hline WKC008 & 37.9802 & -87.4503 & 0.40 & 0.83 & Qlt & $\begin{array}{l}\text { Slackwater deposits, lacustrine terrace (upper } \\
\text { Pleistocene) }\end{array}$ & 3 \\
\hline WKC009 & 38.0781 & -87.4658 & 4.50 & 6.29 & Qlt & $\begin{array}{l}\text { Lacustrine terrace deposit } \\
\text { (upper Pleistocene) }\end{array}$ & 3 \\
\hline WKC010 & 38.0677 & -87.4659 & 0.00 & 0.00 & Qlt & $\begin{array}{l}\text { Lacustrine terrace deposit } \\
\text { (upper Pleistocene) }\end{array}$ & 3 \\
\hline HNC001 & 37.8153 & -87.5922 & 3.18 & 3.19 & Qlt & $\begin{array}{l}\text { Slackwater deposits, lacustrine terrace (upper } \\
\text { Pleistocene) }\end{array}$ & 3 \\
\hline HNC002 & 37.8043 & -87.6669 & 2.67 & 3.30 & Qlt & $\begin{array}{l}\text { Slackwater deposits, lacustrine terrace (upper } \\
\text { Pleistocene) }\end{array}$ & 3 \\
\hline PSY001 & 37.9806 & -87.7167 & 0.56 & 3.38 & Qlt & $\begin{array}{l}\text { Slackwater deposits, lacustrine terrace (upper } \\
\text { Pleistocene) }\end{array}$ & 3 \\
\hline VHC029 & 38.0381 & -87.4728 & 0.02 & 0.09 & Qlt & $\begin{array}{l}\text { Slackwater deposits, lacustrine terrace (upper } \\
\text { Pleistocene) }\end{array}$ & 3 \\
\hline WKC007 & 38.0583 & -87.4729 & 0.00 & 0.02 & Qlt & $\begin{array}{l}\text { Slackwater deposits, lacustrine terrace (upper } \\
\text { Pleistocene) }\end{array}$ & 3 \\
\hline VHCOO4 & 37.9510 & -87.5722 & 1.64 & 2.78 & af1 & Artificial fill, engineered (modern) & 4 \\
\hline VHC012 & 37.9765 & -87.4735 & 8.52 & 9.90 & af1 & Artificial fill, engineered (modern) & 4 \\
\hline $\mathrm{VHC041}$ & 38.0281 & -87.5405 & 0.00 & 0.00 & af1 & Artificial fill, engineered (modern) & 4 \\
\hline
\end{tabular}




\section{Results for the River Alluvium Group}

Cone penetrometer test profiles in the River Alluvium group, which are found primarily within the Ohio River flood plain, (see fig. 1-11) typically have extensive sand and gravelly sand units below about $10 \mathrm{~m}$, and finer silt and clay layers above that. Overall, calculated LPI is high for the River alluvium group. The factor of safety for liquefaction for group 1 profiles is calculated using the method described above. The factor of safety in the deeper, older Ohio River sand and gravel deposits is highly variable below $10 \mathrm{~m}$ in most profiles, primarily because the tip resistance is quite variable (figure $2 A$ ) and sometimes sufficiently high to give the $C R R$ high enough values to resist liquefaction. Those layers that do not have a sufficiently high $C R R$ to resist liquefaction make a large contribution to the LPI. Surprisingly, some profiles with sand units near the surface, such as VHC007, do not have a large LPI, because of very high tip resistances in these units. The intermediate-depth silty sand layers do make a significant contribution to the LPI. The unit in the top $2 \mathrm{~m}$ was identified in many of the CPT profiles in this region as having high clay and clayey silt content. When the soil-behavior-type index of these layers was evaluated, they typically have $I_{c}$ greater than or equal to 2.6 indicating that they are clay layers that are not susceptible to liquefaction (see discussion below).

Figure 5 shows the soil-behavior-type index $I_{c}$ computed for all clay-rich soils in the CPT datasets as a function of normalized friction ratio $F$. Superimposed on this is the domain of susceptible liquefaction from Robertson and Wride (1998) and Youd and others (2001). These layers, indicated with a red ' $\mathrm{x}$ ' for the factor of safety in figure 1-11, do not contribute to the LPI.

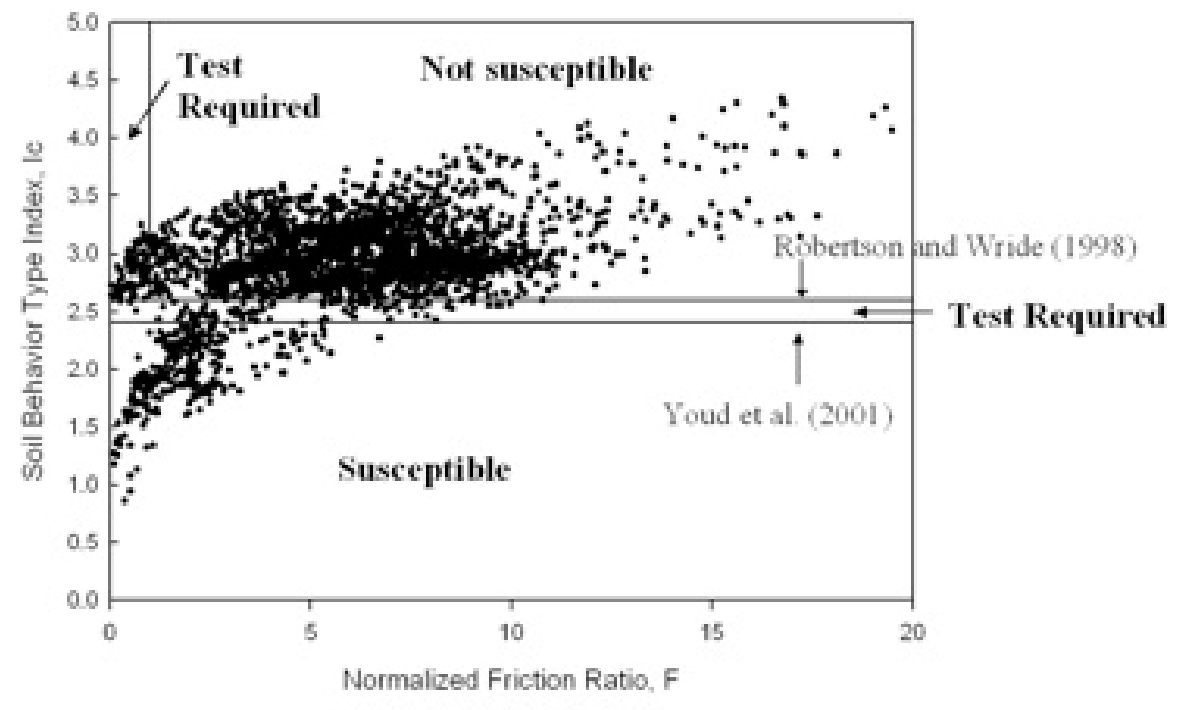

Figure 5. Soil-behavior-type index, $I_{c}$, and friction ratio in percent, $F$, plotted for all clay-rich soil elements in the cone-penetrometer test (CPT) dataset. 


\section{Results for the Outwash Terrace Group}

The soil profiles within the deposits of the Outwash Terrace group are more complex than those in the River Alluvium group, as they contain highly variable sequences of silty sand, clayey sand, and sandy clay from overlapping transitional depositional environments (see figs. 1-12 and 1-13). There is little horizontal continuity of the soils present in these profiles in the terraces north of the current Ohio River flood plain. On the west side of the sampled terrace region, sandy silt and silty sand that may correspond to river overbank deposits appear midway through the profiles. The depths of these deposits vary with distance from the current Ohio River, and extensive layers of clay could be present in locations where the soil profile might be filling in older stream valleys that accumulated clay soils in the lacustrine high-stands (for example, Pigeon Creek).

The farthest west profiles of the sampled terrace region typically have high tip resistance and a resulting high factor of safety for the intermediate-depth sandy silt units in the 3 to $11 \mathrm{~m}$ depth range (see fig. 1-12). Clay units below this depth are predominantly excluded from the LPI calculation, once again because of the $I_{c}$ greater than or equal to 2.6 criterion. Silty sand units below this intermediate depth make a large contribution to the LPI. Toward the center of the sampled terrace region, there are more extensive sandy silt and silty sand units that do not have high tip resistance. These have a much lower factor of safety and contribute greatly to the $L P I$.

The profiles farthest east within the terrace region have most values of $I_{c}$ greater than or equal to 2.6 and therefore have low $L P I$ values. Due to the high variation of the soil properties and the resulting liquefaction potential, it is very difficult to extrapolate the soil-profile properties to nearby sites. In order to construct a liquefaction hazard map for this transition region of terraces between the flood plain and the uplands, a probabilistic method is appropriate.

\section{Results for the Lacustrine Terrace Group}

Profiles in the Lacustrine Terrace group (see fig. 1-14) typically have extensive clay and silt layers in the upper $20 \mathrm{~m}$. The method that is used to calculate liquefaction potential was originally developed for sandy soil, so there is a criterion that the soil-behavior index $I_{c}$ should be less than 2.4 for the method to be used. Soils with behavior index greater than or equal to 2.6 are clay soils that are not susceptible to liquefaction (Robertson and Wride, 1998). This is the case for most of the profiles in the Lacustrine Terrace group. The relatively homogeneous clay layers exhibit different properties in approximately the upper $7 \mathrm{~m}$ where tip resistances are much greater. This results in greater factors of safety. The factor of safety for profiles within the lacustrine region is also shown in Appendix 1. Those data with $I_{c}$ greater than or equal to 2.6 are indicated with a red ' $\mathrm{x}$ ' in the factor of safety profiles. Data with $I_{c}$ between 2.4 and 2.6, which require additional testing to determine their liquefaction susceptibility, are examined in more detail in the next section. Silt and silty clay that have a soil-behavior-type index between 2.4 and 2.6 critically affect the values of $L P I$.

\section{Evaluating Liquefaction Potential for Silty and Clayey Soil}

Generally, two criteria based on soil properties are used to evaluate liquefaction hazard in silty and clayey soils. The first method is based on soil-behavior index $\left(I_{c}\right)$ and the normalized friction ratio $(F)$ from CPT data (Robertson and Wride, 1998). According to the first method, soils are not susceptible to liquefaction if $I_{c}$ greater than 2.6 and $F$ greater than 1.0 percent. Soils with $I_{c}$ between 2.4 and 2.6 or with $I_{c}$ greater than 2.6 and $F$ less than or equal to 1 percent require further laboratory testing before their susceptibility to liquefaction can be determined. Another such testing method was developed by Bray and Sancio (2006) for the evaluation of 
liquefaction susceptibility, which uses the plasticity index and the ratio of water content to the liquid limit to evaluate clayey soils for liquefaction susceptibility.

To examine the extent of this problem in our dataset, soils containing clay-rich layers in the CPT data are plotted on an $I_{c}$-based criteria chart (fig. 5). We presume that soils with $I_{c}$ less than 2.4 will be vulnerable to liquefaction, so the factor of safety is computed and used for the $L P I$. For soils with $I_{c}$ greater than 2.6 and normalized friction ratio $F$ greater than 1.0 percent, we presume that they are not susceptible to liquefaction, so the contribution to $L P I$ is set to zero at that particular depth point even though the factor of safety is less than 1. If the soils lie in the "test required" zone, then the assessment of liquefaction susceptibility requires more investigation. The profiles containing soil layers that fell into this category were confined mostly to a relatively localized region near profiles WKC006 and WKC009 in the northern part of unit Qlt_Lacustrine terrace slackwater deposits (fig. 1).

Because data on the Atterberg limits, a measure of under what water content a soil's mechanical behavior transitions from solid to plastic to liquid, were not collected with this CPT dataset, we used the properties of similar soils from other geotechnical studies in the same localized region (M. Wigger, written comm.), which did include Atterberg limits and the derived plasticity index. These were compiled and plotted on a plasticity index-based criteria chart (fig. 6). From these tests, we see that 80 percent of the soil samples in this region belong to the zone of "not susceptible" to liquefaction. Therefore, we assume that for this case, clay-rich soils that fall into the "test required" region have low probability of being susceptible to liquefaction and make no contribution to the calculation of the LPI. This assumption was retained in the final liquefaction maps.

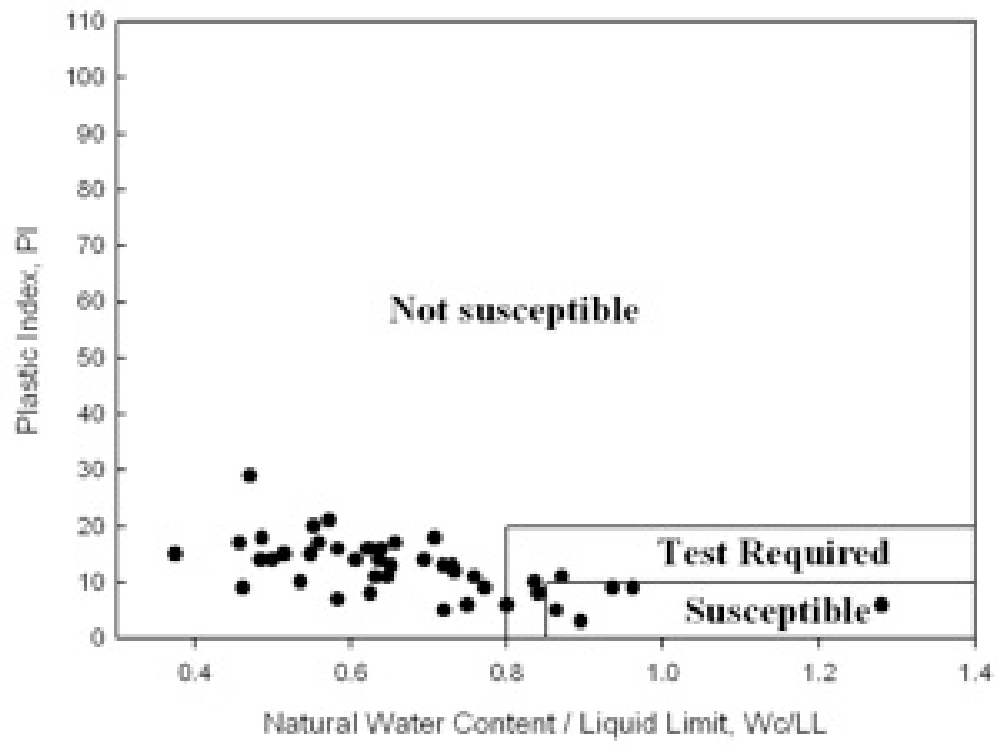

Figure 6. Test datasets of plasticity index, water content, and liquid limit from clay units near the conepenetrometer test profiles within Lacustrine Terrace group that required further testing to determine liquefaction susceptibility. 


\section{Liquefaction Calculation for non-CPT Sites}

\section{Generalization of Soil Profile Type}

There are sufficient CPT data in the three groups defined in table 2 to characterize their properties statistically, even though these data are not uniformly distributed. Loess makes up the majority of the remainder of the surface area. With only two CPT profiles in units containing loess, there were not sufficient data to characterize this statistically; however, these areas typically have a thin layer of silt deposits over bedrock and are not expected to liquefy. Other minor units include artificial fill that we cannot characterize based on their geologic environment. Characterization of these units will require engineering data on their in-situ condition, which is beyond the scope of this study.

To perform the liquefaction-hazard calculation, the CPT properties of tip resistance and sleeve resistance are necessary information. These will be characterized probabilistically for each group. Other required, location-dependent information for calculating the factor of safety and LPI are the total thickness of the soil above bedrock and the depth of the groundwater table. These are obtained separately from the group characteristics.

\section{Determining Soil Thickness and Water Table}

The bedrock depth below the surface was determined from logs and refraction profiles in a previous study, as it was also required for the site amplification calculation for the probabilistic and deterministic hazard analyses (Haase and others, 2011a; Haase and others, 2011b). In brief, the bedrock depth (fig. 7) is based on a compilation of 900 Indiana Geological Survey water well logs from the iLITH database (Bleuer, 2000), 230 bedrock depth measurements interpreted from P-wave refraction profiles (Rudman and others, 1973; Whaley and others, 2002), and bedrock elevation points from the Kentucky Geological Survey oil, gas, and water well logs. Bedrock depth is interpolated using kriging in the uplands regions. Bedrock elevation is interpolated for the lowlands using the bedrock-elevation data. These two sets of contours were merged and refined by hand to replicate the steep-sided bedrock valley walls, then converted to a 50-m raster that optimizes the hydrological continuity on the bedrock surface. The uncertainty in the bedrock depth is plus or minus $3 \mathrm{~m}$. For more details see Haase and others (2011a). 


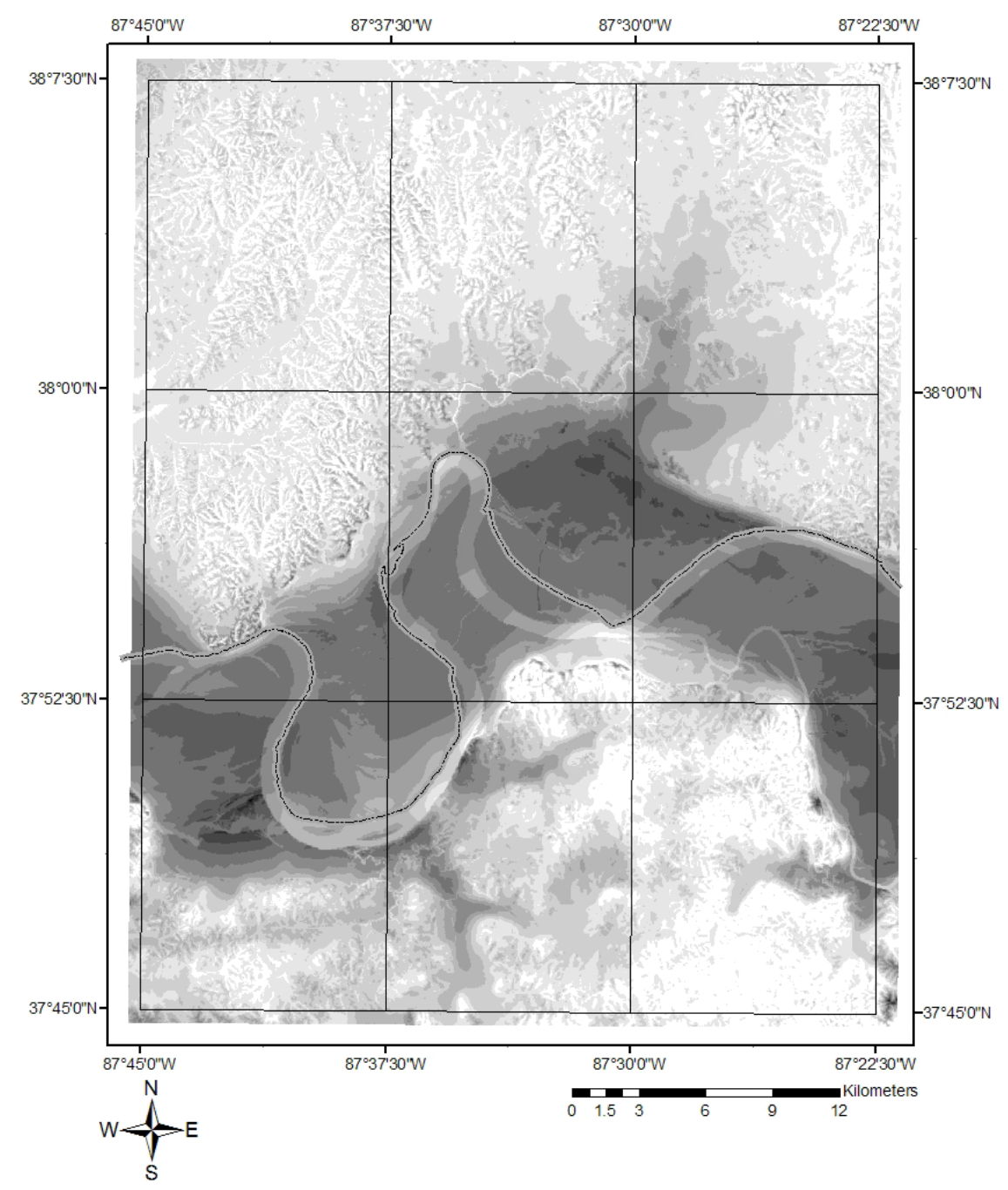

Bedrock Depth (m)

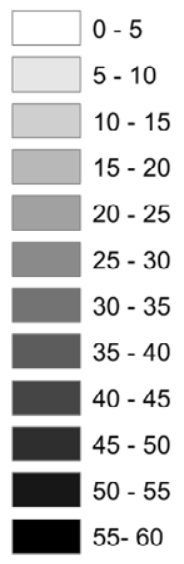

Figure 7. Contoured bedrock depth. The steep-sided ancient bedrock valley is evident beneath the flood plain of the present-day meandering Ohio River. (m, meters).

The depth to the groundwater table affects the calculation of $L P I$, because liquefaction requires saturated soil, and the effective stresses of the soil that determine the resistance to liquefaction depend on the depth below the water table. The groundwater table is quite shallow in this region, and it fluctuates seasonally. The water-well databases available for the region were not useful for determining the groundwater table because they did not contain information verifying whether or not the level provided is the first piezometric surface encountered. Most indicated the piezometric surface of a confined aquifer, as defined by a sealed screen section at depth.

Lacking this information, we constructed water-table depths using an alternative method. Information from the United States Department of Agriculture soil surveys for nearby counties indicates a range of water-table depths from 0 to $2 \mathrm{~m}$ in typical soils. A groundwater surface was 
constructed that followed $2 \mathrm{~m}$ below the surface topography except where bedrock was shallower than $2 \mathrm{~m}$. In that case the groundwater table was set to just above bedrock. The groundwater surface was required to rise linearly from $2 \mathrm{~m}$ to $0 \mathrm{~m}$ at the elevation of the Ohio River. At the locations of the CPT profiles where the groundwater table was measured, there is acceptable agreement with these groundwater-surface values. Based on the statistics of this agreement for each group, an uncertainty of $0.6 \mathrm{~m}$ is assigned to the depth of the water table for profiles within group 1, an uncertainty of $0.2 \mathrm{~m}$ is assigned for group 2, and an uncertainty of 0.8 $\mathrm{m}$ is assigned for group 3.

To assess the sensitivity of the liquefaction hazard to the level of the water table, two sets of calculations were run: one with a high $(2 \mathrm{~m})$ and one with a low $(5 \mathrm{~m})$ groundwater table for the data at the CPT locations. Values of LPI were consistently about 40 percent lower for the lower groundwater table. The more conservative high groundwater table is used in the liquefaction calculations presented here. Future research efforts should collect more data for establishing better constraints on water-table depth, including seasonal variations.

\section{Mapping Liquefaction Potential using a Probability-Based Method}

The approach we applied was to determine at each 0.01 degree grid point in the study region, the distribution of the LPI based on Monte Carlo sampling of the distributions of the sleeve friction and tip resistance. The groundwater-table depth at each point was randomly selected from a distribution with mean given by the depth at the corresponding grid point, with a standard deviation of $0.6,0.2$, or $0.8 \mathrm{~m}$ depth for group 1, group 2, and group 3, respectively. The PGA value was a single value for the appropriate location from the map in figure 3 and was not varied in the Monte Carlo simulations. The bedrock depth below the surface was selected from the map in figure 7 , so that the generic group soil profile was truncated at the bedrock depth if it was less than $20 \mathrm{~m}$ deep.

The CPT data were split into the three groups (table 2). The distributions of tip resistance and sleeve friction in the CPT profiles were evaluated for each group. The lognormal mean and standard deviation of tip resistance and sleeve friction were calculated at every 2-m depth interval. Examples are shown in figure 8 of the variation of properties with depth. Based on these statistics, 25,000 random values of tip resistance and sleeve friction at each 2-m depth interval were generated for each grid point, selecting from the distribution for the appropriate group. We assume no correlation between tip resistance and sleeve friction or between neighboring depth intervals. This fact may reduce the width of the resulting probability density function of $L P I$ (David Perkins, written communication, February, 2011). At each grid point, 25,000 values of $L P I$ were calculated from these profiles. The mean of the $L P I$ values at each grid point was calculated. The spatial distribution of the mean $L P I$ is shown in figure 9 . The calculation was performed individually for each of the two scenario earthquakes of M6.8 and M7.7. 


$$
\frac{11}{11}
$$


$\boldsymbol{E}$

$\boldsymbol{F}$


Figure 8. Examples of the variation of: $A$, the tip resistance, $q_{c}$; and $B$, sleeve friction, $f_{s}$, with depth for all profiles in River alluvium group. Examples of the variation of: $C$, tip resistance, $q_{c}$; and $D$, sleeve friction, $f_{s}$, with depth for all profiles in Outwash terrace group. Examples of the variation of: $E$, tip resistance, $q_{c}$; and $F$, sleeve friction, $f_{s}$, with depth for all profiles in Lacustrine terrace group. (MN, megaNewtons; kN, kiloNewton; m, meter)

23 


\section{A. New Madrid M7.7}

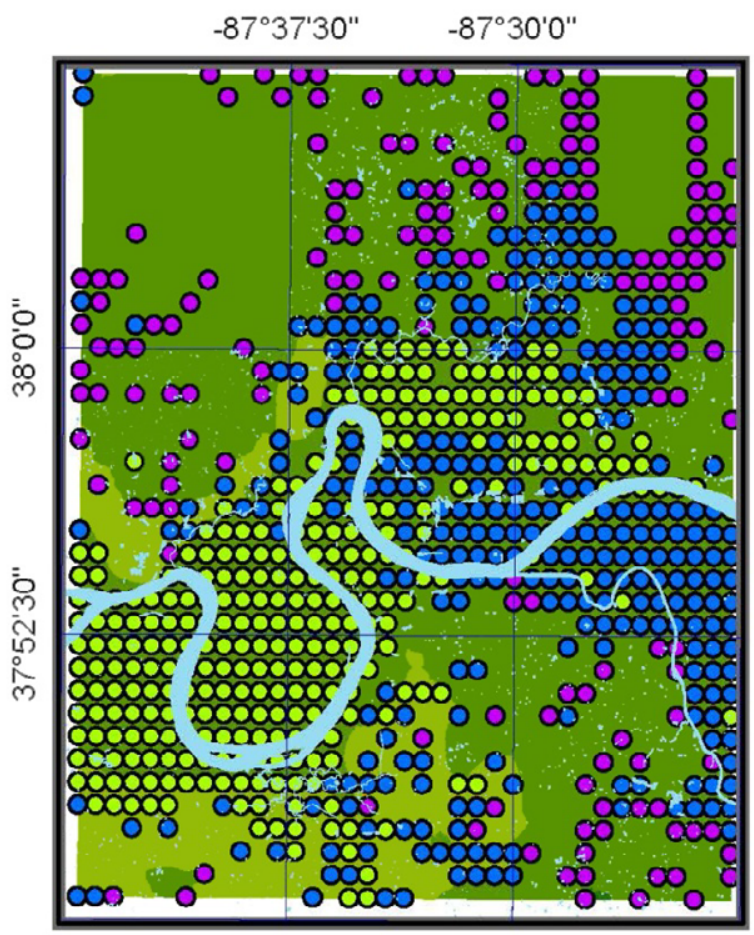

B. Wabash Valley M6.8

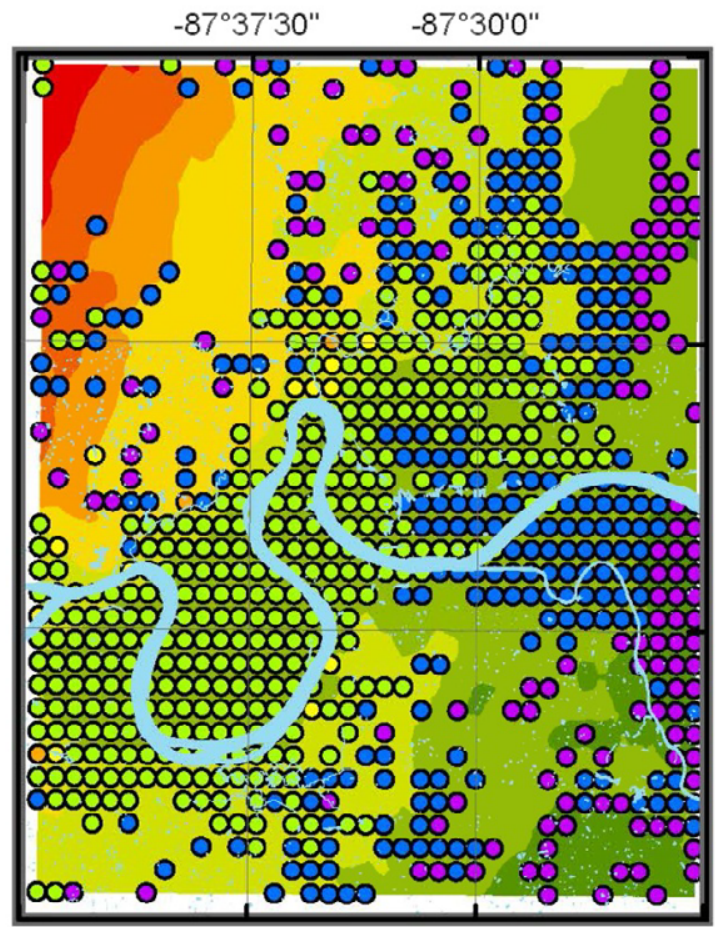

EXPLANATION

\begin{tabular}{clc} 
Average LPI & PGA (g) \\
\hline ○ & $0.00-2.00$ & $0-0.1$ \\
○ & $2.01-5.00$ & $0.1-0.2$ \\
○ & $5.01-12.00$ & $0.2-0.3$ \\
○ & $12.01-15.00$ & $0.3-0.4$ \\
○ & $15.01-20.00$ & $0.4-0.5$ \\
○ & $20.01-30.00$ & $0.5-0.6$ \\
& & $0.7-0.8$
\end{tabular}

Figure 9. Mean liquefaction potential index (LPI) for: $A$, magnitude $(M) 7.7$ New Madrid scenario earthquake and $B, M 6.8$ Wabash River valley scenario earthquake. (PGA, peak ground acceleration; $g$, acceleration of gravity).

From the cumulative frequency distribution of $L P I$ at each grid point, the probability of exceeding $L P I$ of a specific value (5 or 12) for each earthquake was then calculated. These results are shown in figures 10 and 11. 


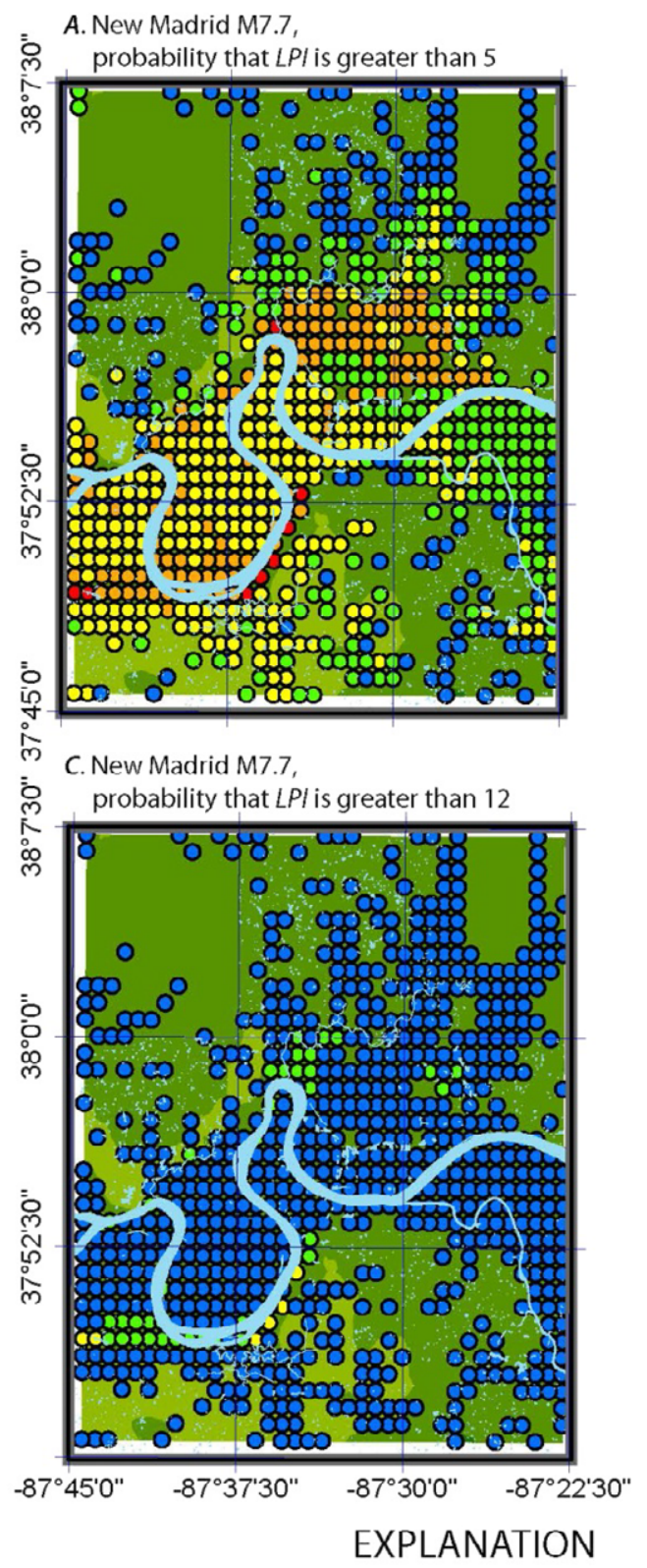

Probability LPI $>\mathbf{5}$ or 12
B. Wabash Valley M6.8,

. probability that $L P /$ is greater than 5

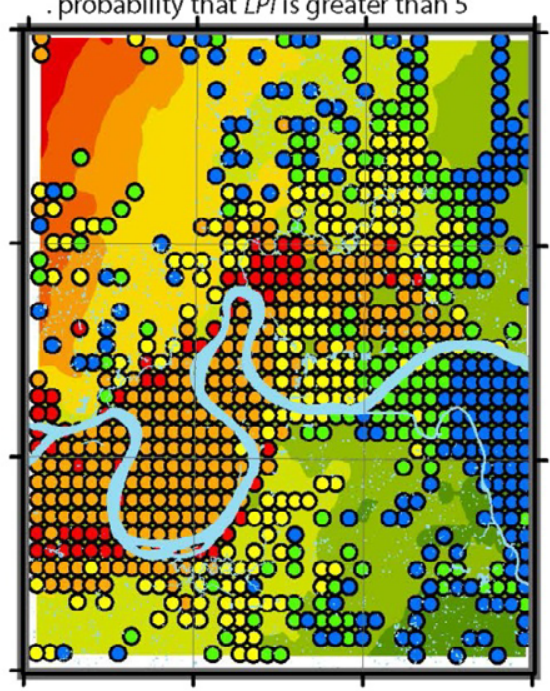

D. Wabash Valley M6.8,

probability that $L P /$ is greater than 12



PGA (g)

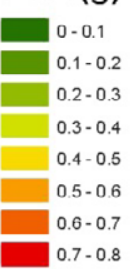

Figure 10. Probability that the liquefaction potential index (LPI) is greater than 5 for: $A$, a magnitude (M) 7.7 New Madrid scenario earthquake and $B$, an M6.8 Wabash River valley scenario earthquake.

Probability that $L P I$ is greater than 12 for: $C$, an M7.7 New Madrid scenario earthquake and $D$, an M6.8 Wabash River valley scenario earthquake. (g, acceleration of gravity). 
For an M6.8 Wabash River valley event, the probability that LPI is greater than 5 (high probability for surface evidence of liquefaction) is about 60-80 percent for the River Alluvium group west of Evansville. For Outwash Terrace group type soils on which most of Evansville is built, the probability that $L P I$ is greater than 5 is about $70-80$ percent. Here the soil sequences are highly variable, so the probability that $L P I$ is greater than 5 can vary greatly. Within the Lacustrine Terrace group, the probability that $L P I$ is greater than 5 is less than 60 percent in most of the area, except in localized areas where PGAs are amplified. For an M6.8 Wabash River valley event, the probability that $L P I$ is greater than 12 (high probability for lateral spreading) is less than 20 percent in almost the entire area for all groups. The exceptions are in the western part of the Outwash terrace where it can reach 60-80 percent and the northern edge of the ancient bedrock valley where ground motions are amplified, leading to $20-40$ percent probability.

For an M7.7 New Madrid earthquake, the probability that LPI is greater than 5 is 40-60 percent for most of the area designated as River Alluvium group west of $-87.5^{\circ}$ longitude, and 20-40 percent east of there. Within the Lacustrine Terrace group, the probability that $L P I$ is greater than 5 is predominantly less than 20 percent north of the Ohio River and 40-60 percent south of the Ohio River. Within the Outwash Terrace group, the probability that LPI is greater than 5 is $60-80$ percent. The probability that $L P I$ is greater than 12 is less than 20 percent almost everywhere for all groups.

\section{Discussion}

By carrying out a scenario calculation, we are implicitly not considering uncertainty in the ground accelerations due to the location or size of the source. Simulations of variations among reasonable assumptions for New Madrid source parameters, however, can lead to a mean shift in PGA.

An M7.7 earthquake was chosen for the scenario because when the hazard is deaggregated, it contributes more than 14 percent of the hazard, whereas an M8.0 contributes only 9 percent and an M7.4 contributes less than 8 percent. An M8.0 scenario earthquake would produce ground motions that are 25 percent higher, on average, than an M7.7 earthquake, and an M7.4 scenario earthquake would produce ground motions that are 20 percent lower, so it is necessary to keep in mind that the liquefaction hazard depends on the assumptions that are made for the source. We estimate that the calculated factors of safety would decrease almost 30 percent for an M8.0 event and increase almost 40 percent for an M7.4 event.

The literature contains many examples of the difficulty of reconciling values and interpretations of LPI calculated using SPT compared to those calculated using CPT (see Holzer, 2008 and references therein). Keeping in mind these limitations, we calculated LPI using both SPT and CPT for a subset of sites where both types of data were available, in order to provide a basis for a qualitative discussion of our results relative to previous results. For the SPT data, we used the method of Youd and others (2001) to estimate liquefaction potential index for an M7.7 event using an $a_{\max }$ value of $0.37 \mathrm{~g}$. There were four sites with several SPT logs available. 
Table 3. Comparison of liquefaction potential index $(L P I)$ calculated using nearby standard-penetration test (SPT) and cone-penetrometer test (CPT) data for several sites within the Lacustrine terrace group. See Holzer (2003) for identification of individual CPT profile locations.

\begin{tabular}{|c|c|c|c|}
\hline SPT Site & LPI & CPT Site & LPI \\
\hline I-164 site 1 & $\begin{array}{l}0.0 \\
0.0 \\
0.0 \\
0.0 \\
0.0 \\
0.0\end{array}$ & VHC030 & 0.06 \\
\hline I-164 site 2 & $\begin{array}{l}0.0 \\
0.12 \\
0.0 \\
0.0 \\
0.0\end{array}$ & VHC029 & 0.19 \\
\hline I-164 site 3 & $\begin{array}{l}0.0 \\
0.0 \\
0.0 \\
\end{array}$ & VHC014 & 0.85 \\
\hline
\end{tabular}

Table 4. Comparison of liquefaction potential index $(L P I)$ calculated using nearby standard-penetration test (SPT) and cone-penetrometer test (CPT) data for several sites within the River alluvium group.

\begin{tabular}{|cc|cc|}
\hline SPT Site & LPI & CPT Site & LPI \\
\hline I-164 site 4 & 34.46 & VHC003 & 37.06 \\
& 31.12 & & \\
& 27.79 & & \\
& 29.89 & & \\
& 21.03 & & \\
& 32.53 & & \\
\hline
\end{tabular}

In this comparison, there was originally a large difference between the $L P I$ calculated based on CPT and SPT data. We found that the high values for LPI from the SPT calculation were due to layers with soil behavior types 1-6 (Robertson, 1990) - in other words, fine-grained clay to silt. Because SPT data can give unreliable and inconsistent results in clays, the discrepancy is not unexpected. Given that these layers would likely be too clay- or silt-rich to liquefy (a similar philosophy as applying a criterion on $I_{c}$ ), we excluded these values from the calculation. After that adjustment, the LPI's calculated from the SPT agreed acceptably with those from CPT data (tables 3 and 4). Having shown that the CPT and SPT data are comparable, we discuss our results in the context of previous studies.

Bobet and others (2001) performed a soil-response analysis at several SPT and borehole shear-wave-velocity measurement locations within the Wabash River valley in southwestern Indiana using the equivalent linear one-dimensional wave propagation analysis method (SHAKE program; Idriss and Sun, 1992). Using the profile of peak acceleration with depth obtained from the soil-response analysis, we compared the actual cyclic stress ratio and the critical cyclic stress ratio required to initiate liquefaction for sites near those in the Bobet and others (2001) study. One site from that study was near site $\mathrm{VHC} 039$ within the lacustrine terrace slackwater deposits 
(Q1t) north of the sharp river bend. This site showed no liquefaction potential in their analysis and had respective LPIs of 0.45 and 0.19 for our analysis for the WVSZ and NMSZ scenarios, thus demonstrating agreement. Their second site was near site VHC035 within the high terrace outwash alluvium (Qot2), just to the east of the sharp river bend. This site showed the CSR exceeding the critical value within the top $8 \mathrm{~m}$ of the profile, for their WVSZ scenario, which agrees with the value of 17.5 (high probability for lateral spreading) calculated for LPI in this study. For the NMSZ scenario, their study showed the CSR just barely reaching the critical value, which agrees with the value of 12.2 (high probability for lateral spreading) calculated for LPI in this study.

Although the Bobet and others (2001) paper discusses only two sites in the two primary types of soils within Evansville, it nevertheless suggests a significant difference in liquefaction potential for these two types of soils. With the high-resolution mapping data, we were able to map out this contrast in properties more clearly, reinforcing our expectation of significantly higher LPI in the River Alluvium group. With a larger dataset our results give a good representation of the variability within each group as well.

Kayabali (1993) produced a map showing the vulnerability of Evansville soils to liquefaction using SPT and the stress-reduction factor determined from CPT data. He used sampled data primarily from within what we called the Outwash Terrace group. The work only evaluated the contribution to LPI from a single layer, which underestimates the liquefaction hazard from the full soil column; however, the general trend of the highest liquefaction potential very close to the Ohio River is consistent with our results. He also found very high variation of liquefaction potential within his smaller map region, which is consistent with our results with large variation of $L P I$ within the Qlot lacustrine and outwash terrace deposit.

Eggert and others (1994) suggested that a more comprehensive evaluation of the liquefaction hazard in the Evansville area should be carried out. Our study complements this earlier study by extending it to a larger study area on both sides of the Ohio River.

The high values of $L P I$ calculated at many sites in this study lead to the question of whether liquefaction has been observed in the geologic record. The known paleoliquefaction feature closest to Evansville is associated with the 12,000 before present (B.P.) event and is located N-NE of Evansville along the Wabash River. At this location, Holocene point-bar or late Wisconsinan braid-bar sands and gravels are overlain by a cap of silty clays (Obermeier, 1998). The next closest features are associated with the 6,100 B.P. event, also along the Wabash River (Green and others, 2005). No evidence of liquefaction was found in a large nearby excavation containing liquefiable sands of younger age beneath a lower terrace near Evansville or in the exposed banks of the Ohio River along the Indiana-Kentucky border (Munson and others, 1997). The authors of that work suggest that the lack of observations indicates that it is likely that the area has not experienced very strong shaking since the 6,100 B.P. event. On the other hand, the authors acknowledge that current river levels might be hiding any liquefaction features that could have developed below the depth of the cap of fine-grained soils in that area, as dams have raised water levels to ensure year round navigation.

\section{Conclusions}

The objective of this study was to provide a detailed map for liquefaction hazard in and around Evansville, Ind. for two scenario earthquakes: an M6.8 Wabash River valley event approximately $40 \mathrm{~km}$ northwest of Evansville and an M7.7 New Madrid event approximately $180 \mathrm{~km}$ southwest of Evansville. These choices are supported by historical liquefaction data in the Wabash River valley and the deaggregation of the probabilistic 2008 USGS National Seismic Hazard Maps. We used cone-penetrometer-test (CPT) data collected by Holzer (2003) that 
sampled the principal surficial geologic map units mapped by Moore and others (2009) as part of the Evansville project. The factor of safety against liquefaction for each CPT location was calculated using a standard method (Robertson and Wride, 1998) based on the cyclic resistance ratio, cyclic stress ratio, and the properties of the soil column.

The calculations show high variability of liquefaction potential index $(L P I)$ for samples in the Outwash Terrace group with higher values in the west, consistent with higher peak ground acceleration (PGA) values found in the site-dependent scenario ground-motion study (Haase and others, 2011b). Higher LPI values are found in the River Alluvium group and low LPI are found in the Lacustrine Terrace group. We established the probability distributions for liquefaction potential for each group using Monte Carlo sampling of the distributions of the properties of individual soil measurements of tip resistance and sleeve friction to determine the probability of exceeding LPI thresholds for surface expression (LPI greater than 5) and lateral spreading (LPI greater than 12). We created maps of both the mean $L P I$ and the probability of exceeding a given $L P I$. The resulting maps quantify the distribution of high liquefaction potential sites in the River Alluvium group where the soil profiles contain more sand; the maps also describe the contrasting Lacustrine Terrace group deposits that predominantly include clayey soil with lower liquefaction hazard.

Local variations of $L P I$ are greatly dependent on local amplification due to site effects. For an M7.7 New Madrid earthquake, the probability that LPI is greater than 5 is 20-60 percent for most of the group 1 units and 20-80 percent for most of the group 2 units. Within the Lacustrine Terrace group, the probability that LPI is greater than 5 is almost everywhere less than 40 percent. The probability that $L P I$ is greater than 12 is less than 20 percent almost everywhere.

The lower probability of LPI being greater than 5 for a New Madrid earthquake is consistent with the fact that liquefaction features have not been found in the Ohio River valley that match documented New Madrid events, although features could have been eroded away (Obermeier, 1998). Also, evidence of liquefaction features from the New Madrid earthquakes appears to be limited to areas south of Saline Creek in southern Illinois (Obermeier, 1996).

For an M6.8 Wabash River valley event, the probability that LPI is greater than 5 (high probability of surface evidence of liquefaction) is about 60-80 percent for most of the River Alluvium group west of Evansville. For Outwash Terrace group type soils on which most of Evansville is built, the probability that $L P I$ is greater than 5 is about $60-100$ percent. Here the soil sequences are highly variable, so the probability that $L P I$ is greater than 5 can vary greatly by location. Within the Lacustrine Terrace group, the probability that LPI is greater than 5 is 0 60 percent. For an M6.8 Wabash River valley event, the probability that LPI is greater than 12 (high probability of lateral spreading due to liquefaction) is less than 20 percent for all groups except at the northern edge of the buried ancient bedrock valleys where ground motions are preferentially amplified. It is therefore possible that since evidence for liquefaction has not yet been found to have occurred in the Evansville area since 12,000 B.P. (Munson and others, 1997), ground shaking levels as have been estimated for a M6.8 Wabash River valley scenario event have not occurred in Evansville since that time.

\section{Acknowledgments}

This work was supported by USGS National Earthquake Hazards Reduction Program grant (07HQGR0058). We thank Tom Holzer and the liquefaction hazard group at the USGS for making the CPT data available. We thank Ron Counts at the Kentucky Geological Survey for providing water well and borehole data. We thank Michael Wigger, from Earth Exploration, Inc., of Indianapolis, Ind. for the supplemental geotechnical data on Atterberg limits in Posey and 
Vanderbergh Counties, Ind. We thank Antonio Bobet for assistance with the liquefaction analysis method. We thank Tim Bowling for his help with GIS calculations. We thank Tom Holzer, Randy Jibson, and David Perkins for thorough reviews that helped improve the clarity and content of this manuscript.

\section{Appendix 1}

This appendix shows the soil behavior type and factor of safety for each soil layer for typical profiles from each of the three groups. Figure 1-1 shows profiles for group 1, River Alluvium, figure 12 shows the western profiles from group 2, Outwash Terrace, figure 13 shows the eastern profiles from group 2, Outwash Terrace, and figure 14 shows profiles from group 3 , Lacustrine Terrace. 
Figure 1-1. Group 1, River alluvium, profiles and calculated factor of safety (FS), with soil units taken from Holzer (2003). Units with soil-behavior index $\left(I_{c}\right)$ less than 2.6 do not contribute to the liquefaction potential index and are indicated with the factor of safety in red.
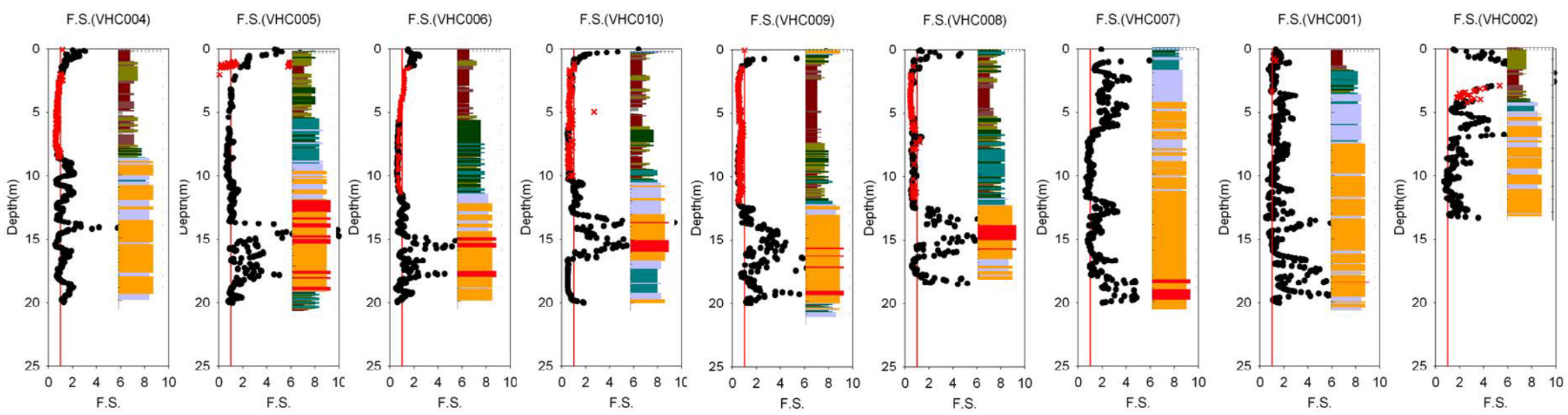
1 sensitive fine grained organic material

4 silty clay to clay

5 clayey silt to silty clay

6 sandy silt to clayey silt

7 silty sand to sandy silt

8 sand to silty sand

10 gravelly sand to sand

11 very stiff fine grained $\left(^{*}\right)$

13 clay

F.S. $=1$

$\times$ Factor of Safety (Ic>2.6)

- Factor of Safety $\left(I_{c}<2.6\right)$ 
Figure 1-2. Western profiles from group 2, Outwash terrace, and factor of safety (FS) with soil units taken from Holzer (2003). Units with soilbehavior index $\left(I_{c}\right)$ less than 2.6 do not contribute to the liquefaction potential index and are indicated with the factor of safety in red.


sensitive fine grained organic material clay
F.S.(VHC006)

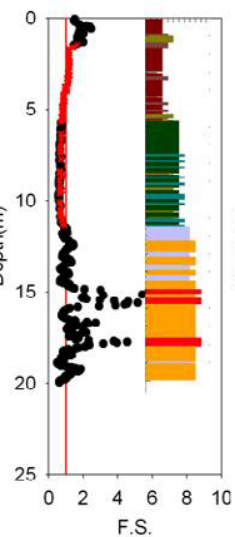

F.S.(VHC010)

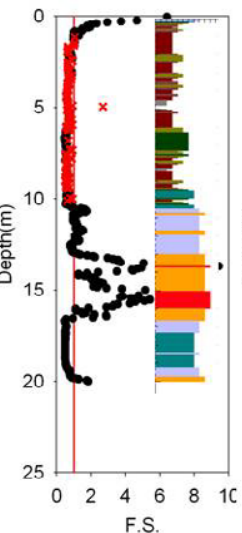

F.S.(VHCOO9)

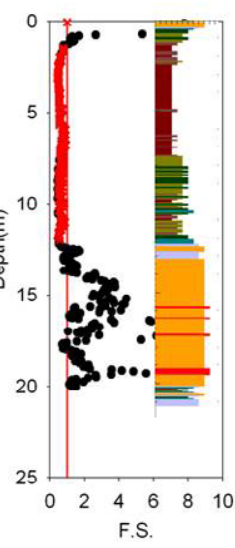

4 silty clay to clay 5 clayey silt to silty clay

6 sandy silt to clayey silt

F.S.(VHCO08)

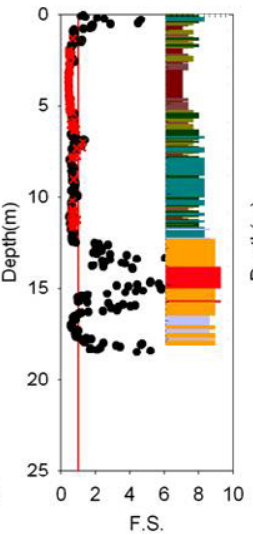

7 silty sand to sandy silt
8 sand to silty sand sand
F.S.(VHC007)

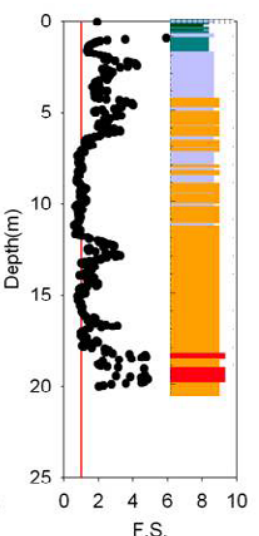

F.S.
F.S.(VHC001)

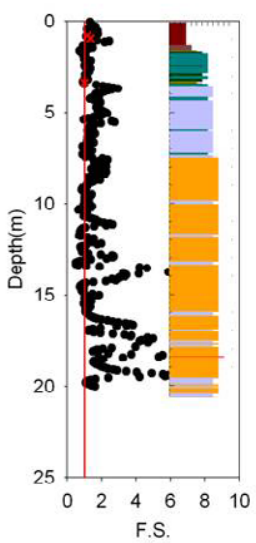

F.S.(VHC002)

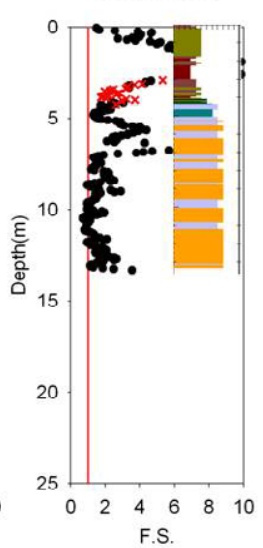

10 gravelly sand to sand

11 very stiff fine grained $\left({ }^{*}\right)$

12 sand to clayey sand $\left({ }^{*}\right)$ 
Figure 1-3. Eastern profiles from group 2, Outwash terrace, and calculated factor of safety (FS) with soil units taken from Holzer (2003). Units with soil-behavior index $\left(I_{c}\right)$ less than 2.6 do not contribute to the liquefaction potential index and are indicated with the factor of safety in red.

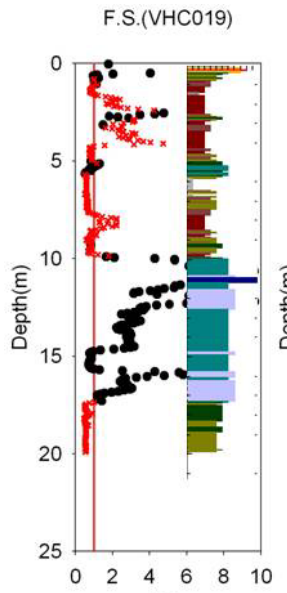

F.S
F.S.(VHC018)



F.S.
F.S.(VHC017)

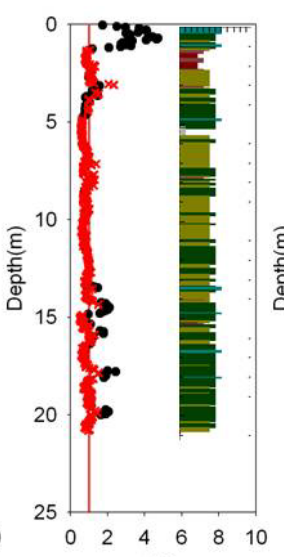

F.S.
F.S.(VHC016)



F.S.
F.S.(VHC015)

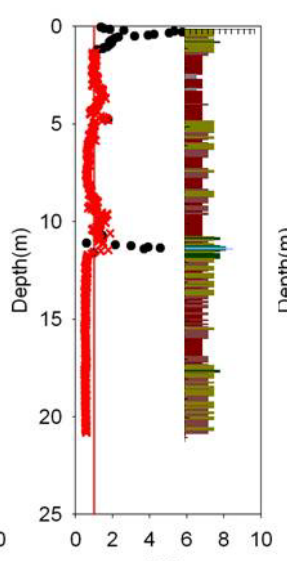

F.S.
F.S.(VHC013)

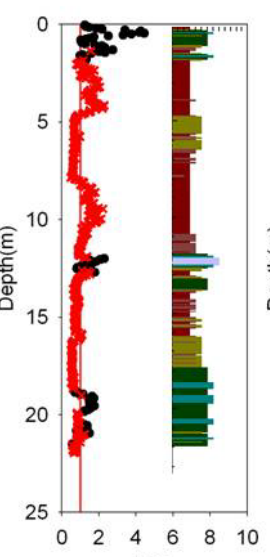

F.S.
4 silty clay to clay

5 clayey silt to silty clay

6 sandy silt to clayey silt
7 silty sand to sandy silt

8 sand to silty sand

9 sand
F.S.(VHC012)

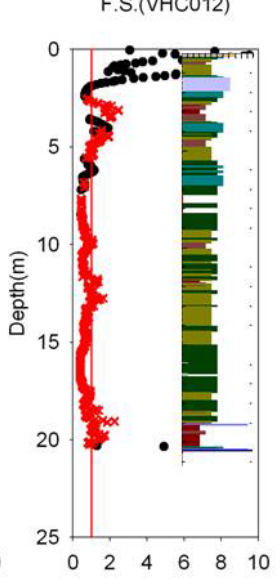

F.S.

2 organic material clay

$$
\text { F.S. }=1
$$

$\times$ Factor of Safety (Ic>2.6)

- Factor of Safety $(I c<2.6)$ 
Figure 1-4. Group 3, Lacustrine terrace, profiles and calculated factor of safety (FS) with soil units taken from Holzer (2003). Units with soilbehavior index $\left(I_{c}\right)$ less than 2.6 do not contribute to the liquefaction potential index and are indicated with the factor of safety in red.

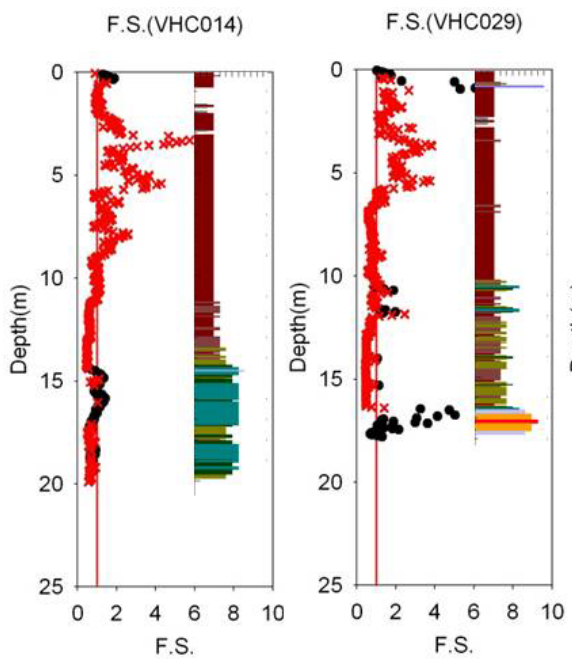

1 sensitive fine grained

2 organic material

3 clay
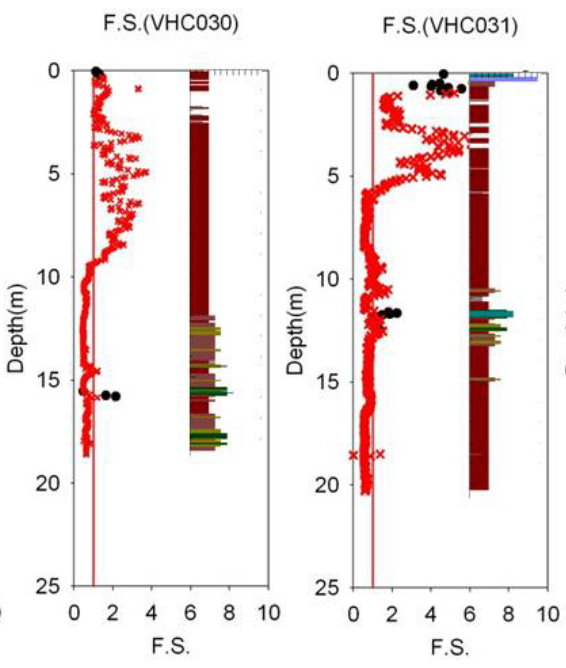

4 silty clay to clay

5 clayey silt to silty clay

6 sandy silt to clayey silt
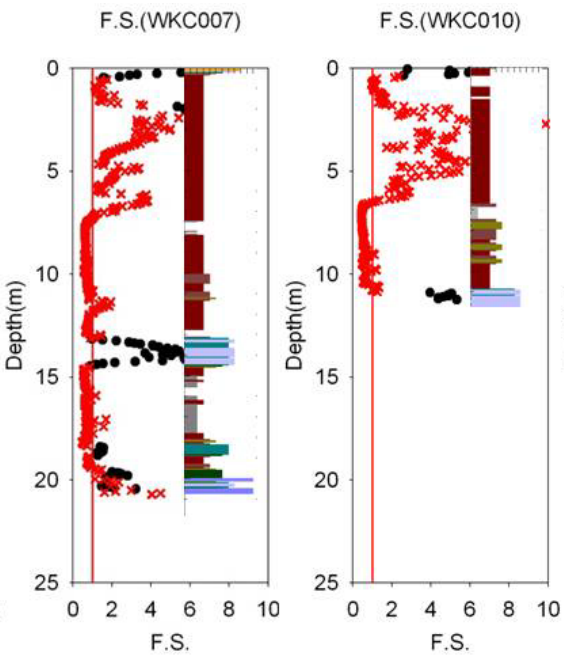

7 silty sand to sandy silt

8 sand to silty sand sand
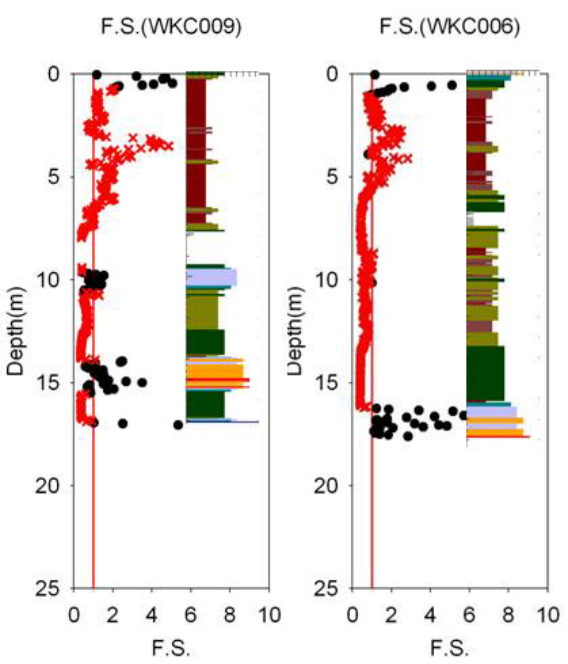

10 gravelly sand to sand 11 very stiff fine grained $\left(^{*}\right)$ 12 sand to clayey sand $\left({ }^{*}\right)$
F.S. $=1$

$X$ Factor of Safety $(I \mathrm{C}>2.6)$

- Factor of Safety $(\mathrm{Ic}<2.6)$ 


\section{References}

Bakun, W.H., and Hopper, M.G., 2004, Magnitudes and locations of the 1811-1212 New Madrid, Missouri, and the 1886 Charleston, South Carolina, earthquakes: Bulletin of the Seismological Society of America, v. 94, no. 1, p. 64-75.

Bleuer, N.K., 2000, iLITH database of the Indiana Geological Survey: Indiana Geological Survey Open File Study 00-8, CD-ROM.

Bobet, Antonio, Salgado, Rodrigo, and Loukidis, Dimitrios, 2001, Seismic design of deep foundations: Purdue University Joint Transportation Research Program Final Report FHWA/IN/JTRP-2000/22, Project No. C-36-36GG, File No. 6-14-33, 93 p.

Bray, J.D., and Sancio, R.B., 2006, Assessment of the liquefaction susceptibility of fine-grained soils: Journal of Geotechnical and Geoenvironmental Engineering, v. 1332, no. 9, p. 1165-1177.

Calais, Eric, and Stein, Seth, 2009, Time-variable deformation in the New Madrid Seismic Zone: Science, v. 323, no. 5920, p. 1442-1442.

Cramer, C.H., 2003, Site-specific seismic-hazard analysis that is completely probabilistic: Bulletin of the Seismological Society of America, v. 93, no. 4, p. 1841-1846.

Cramer, C.H., Rix, G.J., and Tucker, Kathy, 2008, Probabilistic liquefaction hazard maps for Memphis, Tennessee: Seismological Research Letters, v. 79, no. 3, p. 416-423.

Eggert, D.L., Samuelson, A.C., Bray, J.D., Chang, C.W., Eckhoff, W.R., Kayabali, Kamil, McClees, E.J., West, T.R., Woodfield, M.C., and Zheng, B., 1994, Final report to the city of Evansville-Shearwave and earthquake hazard mapping of Evansville, Indiana: Indiana Geological Survey Open-File Study, OFS94-19, 17 p.

Eggert, D.L., Woodfield, M.C., Bleuer, N.K., and Hartke, E.J., 1996, Geologic terrain map of the Indiana portion of the Newburgh quadrangle, Indiana-Kentucky: Indiana Geological Survey OpenFile Study, OFS96-09, scale 1:24,000.

Eggert, D.L., Woodfield, M.C., Bleuer, N.K., and Hartke, E.J., 1997a, Geologic terrain map of the Daylight quadrangle: Indiana Geological Survey Open-File Study, OFS97-17, 2 pls, scale 1:24,000.

Eggert, D.L., Woodfield, M.C., Bleuer, N.K., and Hartke, E.J., 1997b, Geologic terrain map of the Evansville region, Indiana: Indiana Geological Survey Open-File Study, OFS97-16, scale 1:24,000. Gray, H.H., 1989, Quaternary geologic map of Indiana: Indiana Geological Survey Miscellaneous Map 49, scale 1:500,000.

Green, R.A., Obermeier, S.F., and Olson, S.M., 2005, Engineering geologic and geotechnical analysis of paleoseismic shaking using liquefaction effects-Field examples: Engineering Geology, v. 76, p. 263-293.

Haase, J.S., and Nowack, R.L., 2009, Earthquake scenario ground motions for the urban area of Evansville, Indiana: U.S. Geological Survey Final Technical Report \#G09AP00057, 16 p.

Haase, J.S., Nowack, R.L., Choi, Y.S., Bowling, T., Cramer, C.H., Boyd, O.S., and Bauer, R.A., 2011 a, Probabilistic seismic hazard assessment including site effects for Evansville, Indiana, and the surrounding region: U.S. Geological Survey Open-File Report 2011-1231, 29 p.

Haase, J.S., Nowack, R.L., Cramer, C.H., Boyd, O.S., and Bauer, R.A., 2011b, Earthquake scenarios for the Evansville, Indiana, region: U.S. Geological Survey Open-File Report 2011-1260, 17 p.

Harmsen, S.C., Perkins, D.M., and Frankel, A.D., 1999, Deaggregation of probabilistic ground motions in the central and eastern United States: Bulletin of the Seismological Society of America, v. 89, no. 1, p. 1-13. 
Holzer, T.L., 2003, Earthquake Hazards: USGS CPT Data-Evansville Indiana area: United States Geological Survey Earthquake Hazards Program, accessed January $14^{\text {th }}, 2004$, at

http://earthquake.usgs.gov/regional/nca/cpt/data.

Holzer, T.L., ed., 2008, Probabilistic liquefaction hazard mapping: Sacramento, Calif., American

Society of Civil Engineers, v. Geotechnical Special Publication No. 181, p. 1-32.

Holzer, T.L., Bennett, M.J., Noce, T.E., Padovani, A.C., and Tinsley, J.C.I., 2006, Liquefaction hazard mapping with LPI in the greater Oakland, California, area: Earthquake Spectra, v. 22, no. 3, p. 693-708.

Holzer, T.L., Noce, T.E., and Bennet, M.J., 2009, Scenario liquefaction maps of Santa Clara Valley,

Northern California: Bulletin of the Seismological Society of America, v. 99, no. 1, p. 367-381.

Hough, S.E., Armbruster, J.G., Seeber, L., and Hough, J.F., 2000, On the Modified Mercalli Intensities and magnitudes of the 1811-1812 New Madrid earthquakes: Journal of Geophysical Research-Solid Earth, v. 105, no. B10, p. 23839-23864.

Idriss, I.M., and Sun, J.I., 1992, User's manual for SHAKE91: Davis, Calif., Unievrsity of California, Deptartment of Civil and Environmental Engineering, Center for Geotechnical Modeling, 47 p.

Iwasaki, Toshio, Tokida, Ken-Ichi, Tatsuoka, Fumio, Watanabe, S., Yasuda, Susumu, and Sato, Hiroshi, 1982, Microzonation for soil liquefaction potential using simplified methods, in International Conference on Microzonation, $3^{\text {rd }}$, Seattle, Wash., June 28-July 1, 1982, Proceedings: Washington, D.C., National Science Foundation, p. 1319-1330.

Johnston, A.C., 1994, Seismotectonic interpretations and conclusions from the stable continental region seismicity database, in Schneider, J.F., ed., The earthquakes of stable continental regions_-Volume 1, Assessment of large earthquake potential: Palo Alto, Calif., Electric Power Research Institute, p. 4-1-4-103.

Johnston, A.C., 1996, Seismic moment assessment of earthquakes in stable continental regions-III. New Madrid 1811-1812, Charleston 1886 and Lisbon 1755: Geophysical Journal International, v. 126, no. 2, p. 314-344.

Kayabali, Kamil, 1993, Earthquake hazard analysis for the city of Evansville, Ind.: West Lafayette, Ind., Purdue University, Ph.D. dissertation, 382 p.

Kayabali, Kamil, and West, T.R., 1994, Liquefaction susceptibility evaluation for the City of

Evansville, Indiana: Bulletin of the Association of Engineering Geologists, v. 31, no. 2, p. 231-253.

Lenz, J.A., and Baise, L.G., 2007, Spatial variability of liquefaction potential in regional mapping using CPT and SPT data: Soil Dynamics and Earthquake Engineering, v. 27, no. 7, p. 690-702.

McNulty, W.E., and Obermeier, S.F., 1999, Liquefaction evidence for at least two strong Holocene paleo-earthquakes in central and southwestern Illinois, USA: Environmental and Engineering Geoscience, v. 5, no. 2, p. 133-146.

Moore, D.W., Lundstrom, S.C., Counts, R.C., Martin, S.L., Andrews, W.M., Jr., Newell, W.L., Murphy, M.L., Thompson, M.F., Taylor, E.M., Kvale, E.P., and Brandt, T.R., 2009, Surficial geologic map of the Evansville, Indiana and Henderson, Kentucky area: U.S. Geological Survey Scientific Investigations Map SIM-3069, 1:50,000 scale.

Munson, P.J., and Munson, C.A., 1996, Paleoliquefaction evidence for recurrent strong earthquakes since $20000 \mathrm{yr}$ BP in the Wabash Valley area of Indiana: Indiana University Final Technical Report for U.S. Geological Survey Grant \#14-08-0001-G2117, 137 p.

Munson, P.J., Munson, C.A., and Pond, E.C., 1995, Paleoliquefaction evidence for a strong Holocene earthquake in south-central Indiana: Geology, v. 23, no. 4, p. 325-328.

Munson, P.J., Obermeier, S.F., Munson, C.A., and Hajic, E.R., 1997, Liquefaction evidence for Holocene and latest Pleistocene seismicity in the southern halves of Indiana and Illinois - A preliminary overview: Seismological Research Letters, v. 68, no. 4, p. 521-536. 
Nuttli, O.W., 1973, The Mississippi Valley earthquakes of 1811 and 1812-Intensities, ground motion and magnitudes: Bulletin of the Seismological Society of America, v. 63, no. 1, p. 227-248.

Obermeier, S.F., 1996, Use of liquefaction-induced features for paleoseismic analysis - An overview of how seismic liquefaction features can be distinguished from other features and how their regional distribution and properties of source sediment can be used to infer the location and strength of Holocene paleo-earthquakes: Engineering Geology, v. 44, no. 1-4, p. 1-76.

Obermeier, S.F., 1998, Liquefaction evidence for strong earthquakes of Holocene and latest Pleistocene ages in the states of Indiana and Illinois, USA: Engineering Geology, v. 50, p. 227-254.

Olson, S.M., Green, R.A., and Obermeier, S.F., 2005, Revised magnitude-bound relation for the Wabash Valley seismic zone of the central United States: Seismological Research Letters, v. 76, no. 6, p. 756-771.

Petersen, M.D., Frankel, A.D., Harmsen, S.C., Mueller, C.S., Haller, K.M., Wheeler, R.L., Wesson, R.L., Zeng, Y.H., Boyd, O.S., Perkins, D.M., Luco, Nicolas, Field, E.H., Wills, C.J., and Rukstales, K.S., 2008, Documentation for the 2008 update of the national seismic hazard maps: U.S. Geological Survey Open-File Report 2008-1128, 60 p.

Pond, E.C., 1996, Seismic parameters for the central United States based on paleoliquefaction evidence in the Wabash Valley: Blacksburg, VA, Virginia Polytechnic Institute, Ph.D. dissertation, 583 p.

Rix, G.J., and Romero-Hudock, S., 2003, Liquefaction susceptibility mapping in Memphis/Shelby County, TN: Georgia Institute of Technology Final Technical Report for U.S. Geological Survey Grant \#01HQAG0019, 27 p.

Robertson, P.K., 1990, Soil classification using the cone penetration test: Canadian Geotechnical Journal, v. 27, no. 1, p. 151-158.

Robertson, P.K., and Wride, C.E., 1998, Evaluating cyclic liquefaction potential using the cone penetration test: Canadian Geotechnical Journal, v. 35, no. 3, p. 442-459.

Rudman, A.J., Biggs, M.E., Blakely, R.F., and Whaley, J.F., 1973, Statistical studies of Indiana bedrock velocities-Mapping applications: Indiana Academy of Science, v. 83, no. 1973, p. 284-290.

Street, R.L., 1984, The historical seismicity of the central United States-1811-1928: U.S. Geological Survey Final Report for Contract 14-08-0001-21251, 557 p.

Toprak, Selcuk, and Holzer, T.L., 2003, Liquefaction potential index_Field assessment: Journal of Geotechnical and Geoenvironmental Engineering, v. 129, no. 4, p. 315-322.

Tuttle, M.P., Schweig, E.S., Cambell, Janice, Thomas, P.J., Sims, J.D., and Lafferty, R.H., 2005, Evidence for New Madrid earthquakes in A.D. 300 and 2350 B.C.: Seismological Research Letters, v. 76, no. 4, p. 489-501.

Tuttle, M.P., Schweig, E.S., Sims, J.D., Lafferty, R.H., Wolf, L.W., and Haynes, M.L., 2002, The earthquake potential of the New Madrid seismic zone: Bulletin of the Seismological Society of America, v. 92, no. 6, p. 2080-2089.

Whaley, J.F., Blakely, R.F., Like, K.K., and James, C.L., 2002, Seismic refraction data for Indiana (Point Shapefile): Bloomington, Ind., Indiana Geological Survey, accessed Oct. 7, 2002, at http://inmap.indiana.edu/dload_page/geology.html.

Youd, T.L., Idriss, I.M., Andrus, R.D., Arango, Ignacio, Gastro, Gonzalo, Christian, J.T., Dobry, Richardo, Finn, W.D.L., Harder, L.F.J., Hynes, M.E., Ishihara, Kenji, Koester, J.P., Liao, S.S.C., Marcuson, W.F.I., Martin, G.R., Mitchell, J.K., Moriwaki, Yoshiharu, Power, M.S., Robertson, P.K., Seed, R.B., and Stokoe, K.H., 2001, Liquefaction resistance of soils-Summary report from the 1996 NCEER and 1998 NCEER/NSF workshops on evaluation of liquefaction resistance of soils: Journal of Geotechnical and Geoenvironmental Engineering, v. 127, no. 10, p. 817-833. 